\title{
Dividing the Pie: The Determinants of Labor's Share of Income on the
}

\section{Firm Level}

the Determinants of Labor's Share of Income on the Firm Level

\section{Working Paper}

Author(s):

Siegenthaler, Michael (D); Stucki, Tobias

Publication date:

2014-02

\section{Permanent link:}

https://doi.org/10.3929/ethz-a-010088984

\section{Rights / license:}

In Copyright - Non-Commercial Use Permitted

Originally published in:

KOF Working Papers 352 


\section{KOF Working Papers}

Dividing the Pie: the Determinants of Labor's Share of Income on the Firm Level

Michael Siegenthaler and Tobias Stucki 


\section{KOF}

ETH Zurich

KOF Swiss Economic Institute WEH D 4

Weinbergstrasse 35

8092 Zurich

Switzerland

Phone +41446324239

Fax +41446321218

www.kof.ethz.ch

kof@kof.ethz.ch 


\title{
Dividing the pie: the determinants of labor's share of income on the firm level
}

\author{
Michael Siegenthaler* Tobias Stucki ${ }^{\dagger}$
}

February 2014

\begin{abstract}
This paper is the first to study the factors determining labor's share of income on the level of the individual firm, employing an unusually informative panel data set. The empirical examination is concerned with Switzerland which stands out as one of the very few developed countries with a stable labor share. Broadly confirming results from previous cross-country and industry-level studies, we find that the main factor decreasing the labor share in the estimation period is the increase in the share of workers using ICT in the firm. The main reasons why Switzerland's labor share remained almost constant are its relatively slow-rate of technological progress and shifts towards industries with above-average labor shares.
\end{abstract}

JEL-Classification: D33, E25, J24, O30

Keywords: Labor share, factor income distribution, firm-level analysis

*ETH Zurich, KOF Swiss Economic Institute, siegenthaler@kof.ethz.ch. Address for correspondence: KOF Swiss Economic Institute, Weinbergstrasse 35, CH-8092 Zurich. Phone: +41 4463393 67. The authors thank Thomas Bolli, Michael Graff, Jochen Hartwig, Jan-Egbert Sturm, Martin Wörter, and participants at the Young Swiss Economists Meeting for many helpful comments and suggestions on previous versions of this paper. Michael Siegenthaler gratefully acknowledges financial support from the Swiss National Fund (SNF).

${ }^{\dagger}$ ETH Zurich, KOF Swiss Economic Institute, stucki@kof.ethz.ch 
"The ground covered has been diverse - from national accounts to cost functions to fairness - but this has been intentional. [...] There is a great need, particularly at this juncture, to unify the different branches in economics. The link between macro and micro is essential, and economics has suffered from allowing these to go their separate ways. Empirically, the national accounts need to be brought closer to the micro-data on households. Theoretically, the aggregate analysis of distribution needs to look closer at both profits and wages of heterogeneous workers."

Atkinson [2009], in the conclusion of his study on the relevance of factor shares

\section{Introduction}

In the last three decades, the ratio of labor compensation to domestic output, i.e. labor's share of national income, has declined in almost all developed countries. The mirror image of the declining labor share is an increase in profit share in total income [Karabarbounis and Neiman, 2014]. This development-contrasting with the predictions of a constant labor share of most macroeconomic models currently used-implies an increase in economic inequality in the developed world, mainly because labor income is much more evenly distributed than non-labor income [Chechi and García-Peñalosa, 2010, Atkinson, 2009, Glyn, 2009]. Moreover, declining labor's share go hand in hand with more unequally distributed wages. The reduction in the labor share hence accentuates a development which represents a potential thread to social cohesion: namely that the fraction of the population profiting from economic development decreases.

What causes the decline in the labor share? Many potential explanations to this question have been put forward, ranging from technological progress over globalization to institutional changes favoring the bargaining position of capital over the one of labor. However, empirical studies on the determinants of the labor share are either based on country- [e.g., European Commission, 2007, Chechi and García-Peñalosa, 2010] or industry-level data [Azmat et al., 2012, Bentolila and Saint-Paul, 2003, Hutchinson and Persyn, 2012, Elsby et al., 2013]. To the best of our knowledge, the determinants of the 
labor share have so far not been analyzed on the level of the individual firm. ${ }^{1}$ Yet, the firm level appears to be the most natural level of analysis when studying determinants of labor's share, not only because most determinants of the labor share are specific to the production technology or are related to strategic decisions by firms, but also because the "functional distribution of income" is ultimately decided within individual firms.

There are other advantages of switching the focus of attention to the firm level. First, a firm-level analysis enables us to control for composition biases. Indeed, several studies indicate that a substantial fraction of the decline in the aggregate labor share can be attributed to changes in the sectoral composition of the economy [Arpaia et al., 2009, Solow, 1958, Serres et al., 2001, Young, 2010, Elsby et al., 2013]. In an extreme case, aggregate declines in the labor share might be entirely driven by changes in the composition of firms rather than by within-firm changes in labor shares. Clearly, this would have important consequences on the interpretation of the driving forces behind the declines in labor shares.

Second, a firm-level study of the labor share significantly reduces measurement problems of the labor share and its determinants that are specifically prevalent in cross-country analyses. $^{2}$ Third, by exploiting the panel nature of the data as well as additional survey information, we can address more thoroughly than previous papers whether the estimates are affected by biases due to endogeneity or unobserved time-invariant heterogeneity.

The reason for the absence of firm-level studies of the labor share is probably datadriven. In particular, such an analysis requires panel data that include information on labor costs and value added and a broad set of potential drivers of the labor share. The latter are not commonly available in firm-level data sets. Moreover, the data should favorably span a relatively long time period, since studies on the factors determining labor shares are interested in its medium-term structural movements, and not its shortrun business cycle fluctuations.

Our data meet these criteria. We rely on panel data from a Swiss firm-level innovation

\footnotetext{
${ }^{1}$ Also related to our paper are studies analyzing the impact of technological and organizational change on labor demand. These studies, however, focus on the skill-bias in labor demand and do not analyze the impact of these determinants on the functional distribution of income within firms [see Piva et al., 2005 , for an overview].

${ }^{2}$ These problems concern the nominator as well as the denominator and can strongly affect the trends in aggregate labor shares [e.g., Krueger, 1999, Gollin, 2002, Glyn, 2009].
} 
survey based on a representative sample of firms covering the years 2002, 2005, 2008, and 2011. These data provide us with explicit firm-level measures of nearly all potential determinants brought up in the literature, such as the firm's mark-up power, its use of information and communication technology, or international integration (e.g., foreign direct investments or outsourcing). Hence, the data allow us replacing the proxy variables of the potential determinants of the labor share used in the aggregate studies (such as TFP) with explicit firm-specific measures for these potential determinants (e.g. the share of employees using ICT).

Furthermore, due to rich survey information on new tools of workplace organization (i.e. the incidence of team work, the extent of within-firm rotation of employees, and the decentralization of the workplace within the firm), we can examine the importance of a potential determinant of the labor share not analyzed so far. By favoring high- at the expense of medium and low-skilled workers [Piva et al., 2005, Bresnahan et al., 2002, Caroli and Van Reenen, 2001], we expect that organizational changes affect the firmlevel labor share much in the same way as ICT. In a further addition to the literature, we study whether firm's with a higher share of female employees have a systematically lower labor share. This would be expected if female employees are paid below their marginal products while the resulting rent would not benefit the male co-workers but the recipients of capital income.

The empirical examination is concerned with the case of Switzerland. Figure 1 illustrates why this is an interesting case. It shows that Switzerland's labor share has remained practically stable since $1980 .{ }^{3}$ This is in stark contrast to the the labor shares of the other industrialized countries which show a marked decline over the same time period. The constancy of Switzerland's aggregate labor share is all the more puzzling as Switzerland as a competitive small open economy seems to be exposed to the same fundamental changes in the economy as other developed countries. This study provides an examination for why Switzerland may have developed differently.

\footnotetext{
${ }^{3}$ The labor share data stem from the European Commission AMECO database and are adjusted for self-employment following Gollin [2002]. The measure used is compensation per employee as a fraction of GDP at market prices per person employed. The lack of a downward trend in Switzerland's aggregate labor share is even more evident in other measures of the labor share (see, e.g., Figure 3).
} 


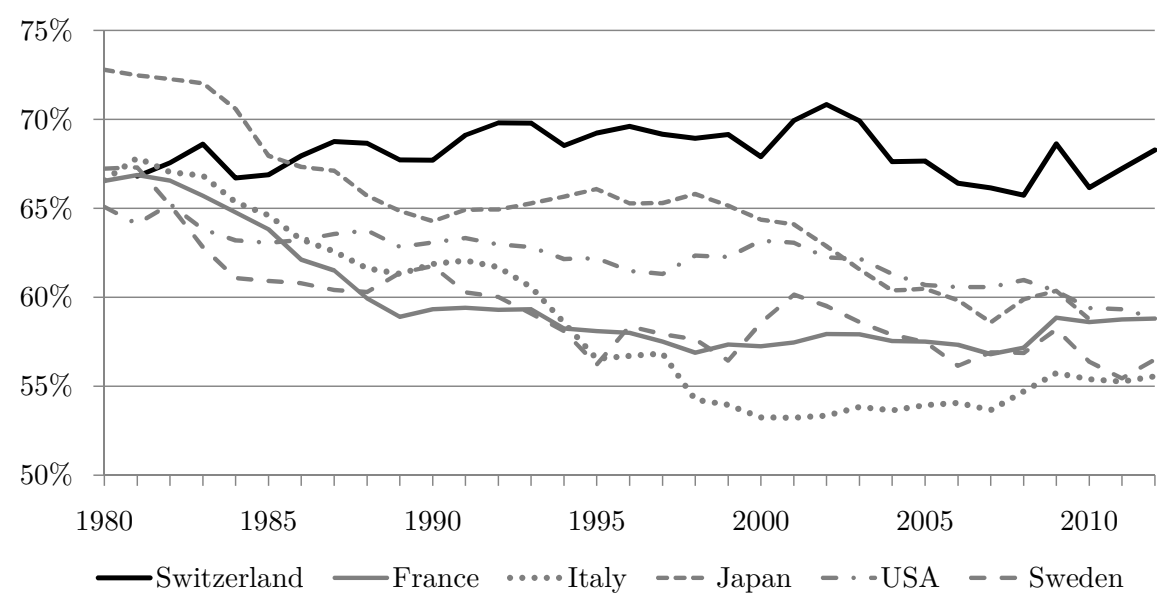

Figure 1: Switzerland as a special case: adjusted labor shares in selected developed countries (1980-2012)

Our firm-level analysis shows that the factors identified to affect the labor share in cross-country and and industry-level studies are indeed shaping the functional income distribution within individual firms. In particular, we find consistent evidence that the firm's use of ICT, new workplace organization practices, increased international integration, and decreased union bargaining coverage are negatively related to labor's share of income, while a decrease in the firm's price setting power has a positive impact. Over the sample period, increased use of ICT and decreased union bargaining coverage contribute the most to declines in firm-level labor shares, while changes in the firm composition towards firms with above-average labor shares are the most important factor increasing it. We also document that compositional effects are an important explanation why Switzerland's labor share has remained practically stable - again highlighting the potential importance of composition biases when studying labor shares on a more aggregate level.

\section{Theoretical framework and hypotheses}

The aim of our paper is to analyze the relative importance of potential drivers of the labor income share on the firm level. In this section, we thus first present a static theoretical benchmark model which helps to understand the determinants of the labor share using 
a simple production function under the assumption of perfect competition in the goods and labor market. We then extend the baseline model in several directions and discuss how this enriches the estimation equation with further potential determinants. We group these determinants into three broad categories: a) production technology, b) openness, and c) institutions.

\subsection{Production technology}

Bentolila and Saint-Paul [2003] show that in a frictionless neoclassical growth model with constant returns to scale in production and labor-augmenting technical change, the labor share is a unique function of the capital-output ratio. To illustrate their reasoning, let us assume that the production function is of the Constant Elasticity of Substitution (CES) type but not necessarily just labor-augmenting, i.e $Y_{i}=\left(\alpha\left(A_{i} K_{i}\right)^{\epsilon}+(1-\alpha)\left(B_{i} L_{i}\right)^{\epsilon}\right)^{1 / \epsilon}$, where $Y_{i}$ is firm $i$ 's output, $K_{i}$ and $L_{i}$ are its respective capital and labor input, and $\epsilon$, $A_{i}, B_{i}$, and $\alpha$ are (potentially firm-specific) technological parameters. In this case, it can be shown that the labor share $s_{L_{i}}$ is given by a monotonic function of the capital-output ratio $k_{i}$ :

$$
s_{L_{i}}=1-\alpha\left(A_{i} k_{i}\right)^{\epsilon}
$$

In this simple framework, the labor share moves together with the capital-output ratio and is shifted by capital-augmenting technical change. ${ }^{4}$ The crucial parameter shaping the magnitude of the association between capital and labor is $\epsilon$, governing the elasticity of substitution between labor and capital. If labor and capital are substitutes $(\epsilon>1)$, a higher capital intensity reduces the labor share. Conversely, if they are complements $(\epsilon<1)$, capital deepening increases the labor share. ${ }^{5}$ Recent papers disagree whether

\footnotetext{
${ }^{4}$ While the assumption of labor-augmenting technological progress is standard in macroeconomics since it ensures the existence of a balanced growth path, the possibility of labor-saving technological progress cannot be ruled out empirically. For instance, firms might direct their innovative expenditures towards labor-saving or labor-augmenting technologies depending on the relative price of capital and labor, or depending on the relative supply of capital and labor [Acemoglu, 2003].

${ }^{5}$ It is important to note that an elasticity of substitution above one is not sufficient to generate long-run trends in the labor share in this neoclassical framework. Trends in the labor share can only be accomodated if $\epsilon>1$ and there is i) capital-augmenting technological progress (i.e. $A_{i}$ grows over time), or if ii) we observe investment-specific technical change driven by reductions in the price of investment relative to the price of output [Elsby et al., 2013]. The latter channel is highlighted by Karabarbounis
} 
the elasticity of substitution between capital and labor is above or below one [cf., e.g., Antràs, 2004, Karabarbounis and Neiman, 2014]. Furthermore, there is no recent estimate of the elasticity of substitution for Switzerland. Accordingly, we postulate the following hypothesis:

Hypothesis 1 (H1): The impact of capital deepening and the labor share is unclear and depends on the aggregate elasticity of substitution between capital and labor.

One important way in which the baseline model above has been extended is by introducing heterogeneous labor, i.e. high- and low-skilled labor are treated as separate inputs to production with differing elasticities of substitution with respect to capital [cf. Arpaia et al., 2009, Bentolila and Saint-Paul, 2003, Elsby et al., 2013]. The main benefit of this extension is that it allows studying the labor share implications of skill-biased technological change, i.e. the notion that technological progress increases the productivity of high-skilled relative to low-skilled workers.

The main factor leading to the skill-bias in technology is thought to be the rapid advancements and diffusion of information and communication technologies (ICT). ICT allows automating routine and well-defined tasks, therefore substituting medium- and probably low-skilled workers in production. High-skilled workers, however, are complementary to ICT because it creates complex tasks involving judgment and creativity, and because adoption and integration of ICT in the firm's productive system is complex [see Acemoglu and Autor, 2011, Piva et al., 2005, for overviews of this literature]. Indeed, most studies examining labor shares using country- or industry-level data argue that a large share of the observed declines in labor shares is due to technological progress and its skill-biased nature due to ICT [IMF, 2007, European Commission, 2007, Lawless and Whelan, 2011]. However, note that the labor share can be constant even if technological progress is skill-biased, as the labor share effect of technological progress depends on the relative effects of technology on skilled and unskilled labor weighted by their respective shares in total labor income [Elsby et al., 2013, Arpaia et al., 2009]. Put differently, the

and Neiman [2014]. 
overall effect of ICT depends on the average workers' ICT complementarity of substitutability. Given these insights, our second hypothesis reads as follows:

H2: Technological progress is positively related to the high-skilled labor share and negatively related to the low-skilled labor share. The overall impact of technological progress on the labor share is not clear and depends on the respective shares in total labor income of workers complemented and substituted, respectively, by technological progress.

Similar to technological progress, also changes in workplace organization have been shown to be skill-biased. In particular, shifts from rigid, Tayloristic, and segmented organizations to a more flexible and "holistic" organization of work [Lindbeck and Snower, 2000] increase the demand for skilled workers at the expense of unskilled workers [Piva et al., 2005, Bresnahan et al., 2002, Caroli and Van Reenen, 2001]. This process of substitution is interlinked with the spread of ICT in firms, as ICT has to some extent enabled the changes in workplace organization. We thus expect that new workplace organization affects the labor share in a similar way as ICT.

H3: Organizational change is positively related to the high-skilled labor share and negatively related to the low-skilled labor share. The direction of the impact of organizational change on the overall labor share is not clear a priori.

\subsection{Openness}

The second most important factor hypothesized to explain long-term downward trends in labor shares next to technology is increased globalization. We focus on two mechanisms through which increased openness of a firm influences the functional income distribution within the firm: outsourcing of tasks and changes in the bargaining position of labor relative to capital.

Studies analyzing the first of these mechanisms, outsourcing, employ models of production with heterogeneous labor and intermediate goods which typically predict that unskilled labor loses from outsourcing, while skilled labor may gain [Feenstra and Hanson, 1999]. Similarly as with ICT, the impact of outsourcing on the total labor share is hence 
theoretically unclear, as the overall effect of outsourcing on the labor share depends on the question whether the gains for high-skilled workers outweigh the losses of low-skilled workers. ${ }^{6}$

The second mechanism we consider focuses on the impact of increased international integration on the position of capital and labor in a strategic bargaining over the gains from production. This political economy approach to trade argues that the main effect of globalization on the functional income distribution is through adversely affecting the relative bargaining position of the least mobile production factor. As the costs of relocating workers are typically much larger than those of relocating capital, openness weakens the bargaining position of individual workers by increasing the outside options of firms [IMF, 2007]. The approach hence predicts that openness profits capital income receivers and hence leads to lower labor shares [cf. Hutchinson and Persyn, 2012, Jayadev, 2007].

H4: The openness of a firm is negatively associated with its labor share through undermining the relative bargaining position of labor vis à vis capital.

The effect of outsourcing depends on the question whether potential gains for high-skilled workers outweigh the losses of low- and medium-skilled workers.

\subsection{Institutions}

One of the main assumptions in the above theoretical model is perfect competition in the goods and labor market, implying that labor is paid according to its marginal product. Dropping this assumption creates rents which can be distributed among production factors [cf., e. g., Blanchard and Giavazzi, 2003].

The size of the rent is determined by the firm's mark-up power, i.e. its possibilities of charging a mark-up over prices. A common proxy for the mark-up power of the firm is the intensity of price competition. A decrease in price competition is expected to raise the firm's possibilities of charging a mark-up over the price. Since price mark-ups are thought to be larger than wage mark-ups, reduced price competition between firms

\footnotetext{
${ }^{6}$ The skill bias in outsourcing has mainly two sources. On the one hand, given the lower general education in developing countries, primarily unskilled labor is relocated from advanced to developing countries. On the other hand, outsourcing of high-skilled workers is more complex than outsourcing of low-skilled worker, resulting in higher costs for outsourcing high-skilled work [Vining and Globerman, 1999].
} 
(i.e. increased mark-up power) is expected to decrease labor's share of income [Azmat et al., 2012, Kalecki, 1971, Blanchard and Giavazzi, 2003]. A recent trade literature, however, suggests that the relationship between competition and the mark-up is not onedimensional. Firms might be able to secure part of their mark-up power when faced with increased price competition by specializing in niche products and products and services of high quality [cf., for instance, Verhoogen, 2008, Baldwin and Harrigan, 2011]. Accordingly, firms' specialization into products shielded from price competition has to be considered to measure mark-up power properly.

H5: The firm's mark-up power is negatively related to the labor share.

The share that labor appropriates from a possible rent in the presence of imperfect competition is thought to depend mainly on degree of organization of the workforce. Through reducing the bargaining position of labor, deunionization or reduced collective bargaining coverage is expected to lead to a decrease in wages by reducing the union wage premium, and assuming a sufficiently inelastic labor demand, also to a decline in the labor share [Bentolila and Saint-Paul, 2003, McDonald and Solow, 1981, OECD, 2011]. Against this background we posit:

H6: Collective bargaining coverage is positively related to the labor share.

\section{Data and measurement of firm-specific labor shares}

The firm data used in this study were collected in the course of four surveys among Swiss companies conducted between 2001 and 2011. All surveys are based on a sample covering the manufacturing industry, construction and business services and are dispro-

portionately stratified (with respect to firm size and two-digit industry affiliation). The data contain answers for 2583, 2555, 2172 and 2363 firms, respectively, representing an average response rate of $37 \%$. The final sample used for estimation is slightly less than 4000 observations due to individually missing observations and the fact that the questions on workplace organization and outsourcing were asked only for firms with more than 20 employees. Because there is a large time lag between the surveys (three years), 
only about $50 \%$ of the firms replied to two successive surveys, meaning that the panel is highly unbalanced.

The main advantage of this data set is that it contains unusually rich information about the surveyed firms. The questionnaires contain, in addition to quantitative information about value added, intermediate inputs, or total labor costs, also items about the use of ICT (internet, intranet, extranet, etc.), the use of new workplace organization practices (team-work, job rotation, employees' involvement in decision-making, etc.), the skill composition of the workforce, and the competitive environment of the firms. ${ }^{7}$ The union coverage rate and average wages of workers in different skill categories were computed from the Swiss wage structure survey conducted by the Federal Statistical Office (FSO) and subsequently merged over the industrial and regional affiliation of the firm. The wage structure survey is a representative survey of all businesses in the second and third sector in Switzerland. It is conducted every two years and samples more than one third of all employees in Switzerland.

Our variable of interest is the firm-specific income share of labor. We measure it as the ratio of total labor costs to value added. Figure 2 relates the unweighted average of the labor shares in our firm sample with two labor share measures of the aggregate Swiss economy. In contrast to certain covariates, the labor share is also contained in the KOF innovation surveys of 1996 and 1999 such that these two cross-sections can be included in the figure, too.

The figure demonstrates that there exists a reasonably close correspondence between the average firm-level labor shares and the aggregate ratio of compensation of employees relative to GDP, computed using the Swiss national accounts. As is illustrated as well, this correspondence even appears for the average labor share computed using the estimation sample only, giving us some confidence that our firm-level analysis can also shed some light on the determinants of the movements in the aggregate Swiss labor share. ${ }^{8}$

\footnotetext{
${ }^{7}$ The questionnaires can be downloaded from www.kof.ethz.ch/en/surveys.

${ }^{8}$ The figure also contains the adjusted labor share measured that had already been used in Figure 1. This measure consistently lies on a higher level compared to the firm-level measure of the labor share, which is due to the fact that the latter disregards the labor income of self-employed which is imputed in the former. Omitting incomes of self-employed is not problematic as including earnings of self-employed might even confound the analysis. Firstly, self-employed persons generally face substantial difficulties to disentangle labor from capital income. Secondly, most potential determinants explaining changes in the labor share such as outsourcing or ICT conceptually affect the share of income accruing to employees,
} 


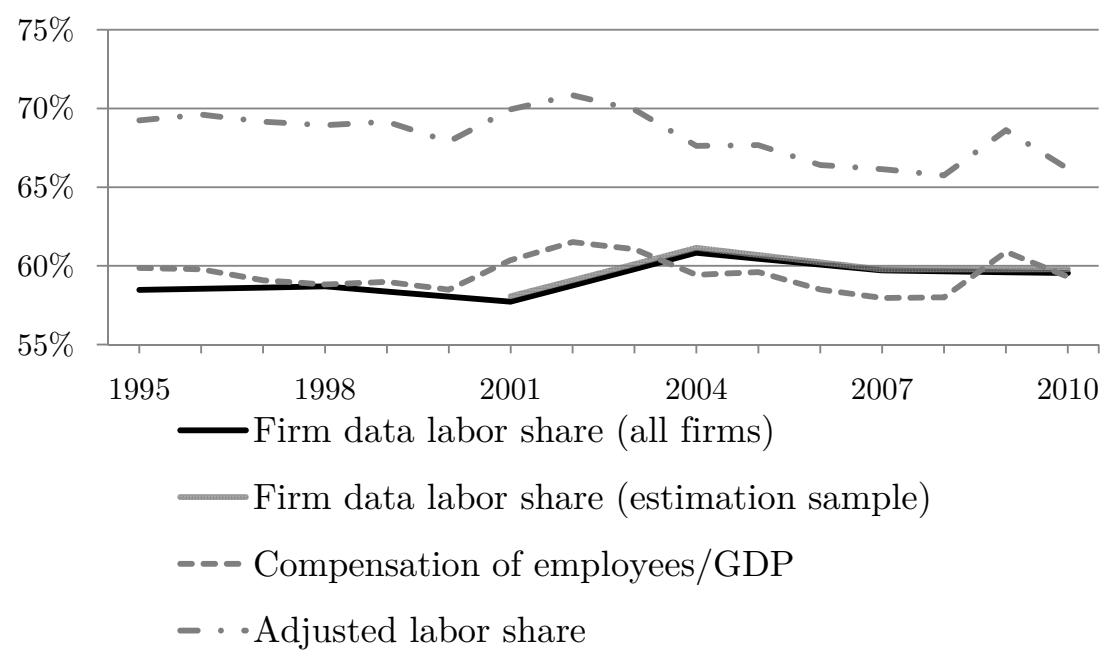

Figure 2: From micro to macro: relationship between firm-level and aggregate labor shares

As was discussed in the last section, many of the potential determinants of the firmlevel labor share have an ambiguous effect on workers with differing skills. In order to illustrate this heterogeneity, we examine potential determinants of the income shares of workers separately for three different skill categories, defined in terms of three educational groups. ${ }^{9}$ However, our firm data only contain data on the total wage bill and the number of employees in the different skill groups. We lack information on the skill-group specific average wage in the firms. Similarly as Caroli and Van Reenen [2001], we approximate these wages using average wages in similarly sized firms in the firm's narrowly defined industry (cf. Appendix 9 for more details).

\section{Methodology}

\subsection{Empirical specification}

Log-linearizing Equation 1 and enriching it with further potential determinants of the labor share as in Bentolila and Saint-Paul [2003] yields a basic estimation equation of the

while potentially favoring the share of self-employed.

${ }^{9}$ The category low-skilled workers subsumes untrained and partly trained employees plus apprentices (ISCED 1 and 2). Medium-skilled workers have completed vocational education and training (ISCED 3 ), and high-skilled workers are employees with a degree above basic vocational education and training (ISCED 4-6). 
$\log$ labor share in firm $i$ and year $t$ :

$$
\ln \left(s_{L_{i t}}\right)=\beta_{0}+\beta_{1} \ln \left(k_{i t}\right)+\beta_{2} \mathbf{A}_{\mathbf{i t}}+\beta_{3} \mathbf{Z}_{\mathbf{i t}}+\beta_{4} \mathbf{X}_{\mathbf{i t}}+\gamma_{1} c_{t}+\gamma_{2} j_{t}+v_{i t}
$$

Following the discussion in Section 2, the labor share depends on the firm-specific capital-output ratio $\left(k_{i t}\right)$, technical progress $\mathbf{A}_{\mathbf{i t}}$, as well as a set of other potential factors affecting the labor share through shifting the share-capital relationship (subsumed in $\mathbf{Z}_{\mathbf{i t}}$ ). Our baseline model includes industry-time effects $\left(j_{t}\right)$ on detailed (NACE rev. 1.2 twodigit) level which control for factors affecting all firms in the same industry equally such as aggregate or industry-specific demand shocks, (factor) price movements, or industry specifics in production. Similarly the canton-time effects $\left(c_{t}\right)$ account for all sorts of policies (e.g., labor income taxes or regulations) that might affect the profitability or labor costs of firms. Many such policies are canton-specific in Switzerland.

We proxy the firm's capital-output ratio by gross investment relative to value added (investment-output ratio henceforth) in the current year (cf. Table 1 and Section 9 in the Online Appendix for a detailed discussion of the way we build model variables) ${ }^{10}$ Clearly, annual gross investments might be a crude proxy for the capital stock of firms, and, moreover, the level of investment might be affected by unobserved shocks simultaneously affecting investment and the labor share (to the extent that these are not accounted for by the set of control variables $\mathbf{X}_{\mathbf{i t}}$ and the fixed effects). The results concerning this variable are hence to be interpreted with caution. However, we will present results for a subsample of firms for which we dispose of a better measure of the capital-output ratio.

Firm-specific technological progress $\mathbf{A}_{\mathbf{i t}}$ is a vector comprising the intensity of the firm's ICT use (the average of the shares of employees using computers, intranet and internet, respectively) and its number of new patents within the last three years. It also contains a composite variable measuring firm's use of new workplace organization practices. This variable subsumes the incidence of team work, the extent of within-firm rotation of employees, and the decentralization of competences in the firm. ${ }^{11}$

The openness of the firm is approximated by the share of exports in turnover, revealing

\footnotetext{
${ }^{10}$ When taking logarithms, 69 firms for which gross investments are zero are dropped.

${ }^{11}$ The variable is implicitly first-differenced by the way the survey question is asked since it refers to changes in workplace organization implemented in the past five years.
} 
whether and to what extent the firm is integrated in foreign trade; a dummy variable indicating foreign ownership, hence signaling inward foreign direct investments (FDI) and the mobility of capital; and a variable capturing whether the firm has outsourced highand low-skilled tasks in the past five years.

Finally, $\mathbf{Z}_{\mathbf{i t}}$ contains two variables capturing institutional determinants of the labor share. The first is the fraction of collectively negotiated wage contracts within the threedigit industry and NUTS-II region of the firm for a given year. ${ }^{12}$ Since there is no state-governed minimum wage in Switzerland, collective labor agreements often contain regulations about minimum wages such that the coverage rate is likely to be correlated with the presence of a minimum wage in the particular industries and regions.

The second institutional variable is the firm-specific mark-up power. This variable i) decreases in the number of competitors which the firm reports to have, ii) decreases in the perceived intensity of price competition, and iii) increases in the perceived intensity of non-price competition. The positive association between mark-up power and perceived non-price competition is motivated by the idea discussed above that it is only firms which have specialized in high quality products and niche markets that perceive that the nonprice component of competition in their main market is high. These firms are therefore likely to be able to set a higher mark-up for a fixed number of competitors.

\subsection{Dealing with endogeneity}

Our aim is to estimate the coefficients of Equation 2 such that they have a causal interpretation in line with the theoretical framework outlined above. However, estimating Equation 2 is likely to be subject to endogeneity particularly due to unobserved third factors and reverse causality. We are not able to address these endogeneity concerns using quasi-experimental methods since this would require exogenous variation for all potentially endogenous drivers of the labor share which are of interest to us. This seems hardly feasible. Our approach is thus i) to minimize potential endogeneity problems in our baseline model, ii) to provide substantive evidence that the model is robust to

\footnotetext{
${ }^{12}$ The measure comprises collective wage agreements between unions and employer organizations, agreements subject to public law, and firm-level contracts. The results are similar if the latter are excluded from the analysis.
} 
re-specifications, and iii) to provide evidence that the results are not driven by reverse causality.

The first potential endogeneity problem are time-invariant omitted factors affecting the labor share and the covariates. Such factors can be controlled for by our use of panel data. However, we do not control for firm fixed effects (FE) in our baseline estimation. First, one desirable feature of over data set is its representativeness, allowing us to study whether changes in the firm composition affect the aggregate labor share. This would not be possible as soon as we restrict ourselves to incumbent firms. Second, a FE estimation is specifically inefficient in our setting ${ }^{13}$. A FE estimation therefore appears overly restrictive as a baseline strategy. We rather prefer to exploit cross-sectional variation in labor shares and its determinants and to demonstrate in the robustness section that our baseline results hold if control for firm fixed effects. In fact, these FE estimations indicate that the substantial set of control variables of the baseline estimation are sufficiently reducing potential biases arising from unobserved firm heterogeneity.

Regarding time-varying omitted third factors, the most important concern are unobserved demand or productivity shocks simultaneously affecting the labor share and the covariates, giving rise to spurious correlations between the two. We reduce such simultaneity biases in three ways. Firstly, we measure certain explanatory variables in such a way that simultaneity is limited in the first place. In particular, some of our variables of interest refer to firm actions made in the past (workplace organization, outsourcing, and new patents), or are measured on the region-industry level (coverage rate). Moreover, we present a robustness check in which we also lag all other contemporaneously determined variables by three years.

Secondly, the vector of control variables $\left(\mathbf{X}_{\mathbf{i t}}\right)$ includes measures accounting for the firm-specific demand situation. In particular, all estimations contain two categorical variables revealing the firm's perception about the demand development in the main market

\footnotetext{
${ }^{13}$ The inefficiency of a FE estimation in our setting stems mainly from three sources. Firstly, data from firm surveys tend to suffer from (classical) measurement error. Estimating a firm fixed effects model aggravates potential attrition biases. Secondly, our panel is highly unbalanced, such that the number of observations that can be used for estimating FE models is substantially lower then the firm sample in the pooled OLS case. Thirdly, not only the labor share, but also its potential determinants are structural characteristics of the firm's production function, its medium-term strategic decisions, and the market in which it operates. Therefore, there is only little within-firm variation that could be exploited to uncover the relationships we are interested in when accounting for FE.
} 
in the past three years and, potentially importantly, about its expectations concerning demand in the next three years.

Thirdly, we add the log of the ratio of intermediate inputs to value added and the square of this variable to the set of control variables. The theoretical rationale behind this inclusion comes from Levinsohn and Petrin [2003] in the context of estimating production functions: if firms are hit by unobserved demand shocks, they respond by adjusting their variable inputs. One easily modifiable input is intermediate inputs. As intermediate inputs are subtracted from turnover when computing value added, they do not directly affect the cake to be distributed among labor and capital. Therefore, controlling for the contemporaneous co-movement of intermediate inputs and the labor share nets out potentially confounding simultaneous co-variation in the labor share, the covariates, and the residual of the regression, obscuring the structural relationships that we aim to uncover. ${ }^{14}$ Our baseline regression hence identifies the parameters of interest exploiting within-industry, within-cantonal variation in labor shares of firm's with similar size and age, controlling for the firm-specific demand situation.

Endogeneity in our estimations might also arise due to reverse causality. Suppose for example that outsourcing of tasks decreases the labor share. However, it is only unprofitable firms with high labor cost shares which actually engage in outsourcing, i.e. the high labor cost share determines outsourcing rather than vice versa. In this case, outsourcing is concentrated in firms with high labor shares. In a cross-sectional regression, one might then erroneously conclude that outsourcing increases the labor share while in fact outsourcing has led to a decrease within the firms. Similar thoughts apply to other variables of interest in our model.

We present several pieces of evidence that reverse causality does not drive our results. Firstly, lagging explanatory variables as was done to reduce simultaneity also limits potential concerns due to reverse causality. Secondly, we demonstrate that the baseline

\footnotetext{
${ }^{14}$ These presumptions are confirmed empirically. Including this variable tends to make the model more stable and the coefficients are more precisely estimated. The inclusion of the variable has two further benefits. Firstly, it helps to control for differential elasticities of substitution between labor and intermediate inputs in the production of firms. Secondly, it partially accounts for firm-specific relative price movements between intermediate inputs and the output good. This benefit arises due to the fact that the ratio of intermediate inputs to value added is expressed in nominal terms. The ratio is thus - to the extent that the industry- and canton-time effects do not absorb them-also influenced by changes in the relative price of intermediate inputs to the price of the output good.
} 
results are robust to the inclusion of the lagged labor share, partially accounting for the possibility that firm actions are driven by a high (or low) past labor share. Thirdly, our results are robust to the inclusion of a variable indicating whether a firm suffers from lack of internal funding. Finally, survey information on whether the firm is innovating in order to reduce the labor cost share allow us showing that our baseline results do not differ between firms which aim to reduce the labor share and firms that do not.

\section{Main results}

Table 2 presents the results of our baseline regressions. The outcome variable in Column 1 is the log labor share in the firm. Since many determinants of the labor share are expected to affect skilled and unskilled workers differentially, Columns 2-4 present the results when decomposing the labor share into the firm-level income shares of high-, medium-, and low-skilled workers, respectively. These regressions illustrate that absence or weak correlation between a potential determinant and the total labor share does not mean that the individual driver does not influence relative labor demand. Since the error terms across these three regressions are correlated, we estimate them jointly using a seemingly unrelated regression model (SUR). Standard errors are robust to clustering at the firm level in all estimations. ${ }^{15}$

The top row of Table 2 provides indicative evidence that the labor share and the investment-output ratio are positively related. Taken at face value, this result suggests that on the elasticity of substitution between capital and labor is below one, holding all other covariates constant - in particular, the firm's use of ICT. As mentioned, however, gross investments relative to value added might be a flawed proxy for the firm's actual capital-output ratio. The most convincing evidence in favor of the first hypothesis therefore comes from a regression in Column 5 of Table A.3 in the Online Appendix in which we approximate the firm's capital stock using the firm's average net investment into machinery, equipment, and buildings in the four years prior to the survey. ${ }^{16}$ The

\footnotetext{
${ }^{15}$ In an alternative specification presented in the Appendix (Table A.4), we cluster standard errors on the industry-region level. This model yields consistent standard errors for the coverage rate since this variable only varies on this level of aggregation. The adjustment has only little effects on the estimated standard errors. In particular, the coefficient of the coverage rate remains statistically significant.

${ }^{16}$ Since these data are only available for the subsample of firms that also participated in the quanti-
} 
coefficient of this better measured capital-output ratio has approximately double the size than the coefficient of the investment-output ratio for the same sample. This indicates that the positive effect of capital deepening on the labor share might be underestimated in our baseline specification. ${ }^{17}$

The measures of technological progress-ICT use and the number of new patentsshow the expected skill-bias in labor demand: firms with a higher use of ICT distribute a higher share of income to high-skilled workers and a lower share to medium- and low-skilled workers (cf. Columns 2-4). Similarly, patents are negatively related to the labor share of low- and medium-skilled workers but have no effect on the labor share of high-skilled workers. Interestingly, the skill-group specific regressions indicate that ICT primarily substitutes low-skilled workers while it does not harm medium-skilled workers (workers with an apprenticeship). This robust result ${ }^{18}$ might appear to contrast with several recent studies showing that ICT growth "polarized" labor demand, i.e. increased demand for challenging tasks and decreased demand for routine tasks generally conducted by medium-skilled workers, while leaving manual tasks generally done by low-educated workers unaffected [Acemoglu and Autor, 2011, Michaels et al., 2013].

A potential explanation for this finding made in similar form in other studies [Hollenstein and Stucki, 2012, Puhani, 2005, 2003] is that the result is driven by Switzerland's strong focus on vocational education and training (VET). The VET system, which combines education at vocational schools with work in the training companies, seem to have the effect of making newly trained apprentices used to ICT tasks, and therefore shields them from being substituted by ICT later in life. A second potential effect of the VET system relates to the idea that current apprentices are not allocated to jobs which are subject to routinization by ICT, since firms decide themselves which type of apprenticeships they offer, aligning the skills of their apprentices to the firm's production. Rather, it is older workers with VET degree and low-skilled workers which perform procedural

tative KOF investment surveys, this leads to a substantial drop in sample size.

${ }^{17}$ Importantly, the improvement in the measurement of the capital-output ratio has no effect on the coefficients of the other covariates.

${ }^{18}$ Firstly, it holds if we employ the firm's ICT investment to output ratio as a measure of the firm's ICT intensity. Secondly, it also holds if we look at the relative wage bill shares of low- or medium-skilled workers, respectively, rather than the relative share in total income. Thirdly, it does not depend on the specific set of control variables. In particular, it is robust to controlling for firm fixed effects. 
and codifiable tasks which are subject to replacement by ICT, potentially explaining why the latter group of workers is suffering most from substitution by ICT. ${ }^{19}$

Since the labor shares of the three skill categories approximately add up to the total labor share in Column 1, one can roughly compute the effect of increased ICT use on the overall labor share by weighting the skill-group specific coefficients by their respective fraction in the total labor share (shown in the top row of Table 2). ${ }^{20}$ This yields an overall coefficient which indicates that the positive effect of ICT use on the labor share of highskilled workers does not compensate the negative effect on the labor share of low-skilled workers. The estimated coefficient implies that a 10 percentage point increase in the average shares of workers using computer, internet and intranet, respectively, decreases the labor share by 1.44 percent.

The negative effect of technological progress on the labor share is confirmed for the second technology variable. The labor share decreases in the number of new patents that the firm had in the three years prior to the survey. In line with hypothesis 3 , also the introduction of measures of new workplace organization practices is associated with a lower labor share. Intensive use of new workplace organization is biased against low-skilled workers. Because this negative effect slightly dominates the positive effect of new workplace practices on high-skilled workers, a one standard deviation increase in the workplace organization variable decreases the overall labor share by $2.3 \%$.

The regressions provide convincing and robust evidence in favor of hypothesis 4 , i.e. the openness of a firm is negatively related to the share of income that it distributes to labor. Labor gets a lower share of value added in export-oriented firms and in firms with outsourcing activities in the past three years. The most striking of these result is the substantial negative effect of foreign ownership on the labor share. The point estimate in the table suggests that the labor share is $5.4 \%$ smaller in foreign-owned firms conditional on all other controls. ${ }^{21}$

\footnotetext{
${ }^{19}$ These hypothesis will be examined in more detail in a future research project.

${ }^{20}$ The computation is not exact since the shares add up to 1 before taking logarithms. However, $\ln \left(\left(L^{H S}+L^{M S}+L^{L S}\right) / Y\right) \approx \ln \left(L^{H S} / Y\right)+\ln \left(L^{M S} / Y\right)+\ln \left(L^{L S} / Y\right)$.

${ }^{21}$ The negative association between the labor share and measures of firm's openness is primarily driven by a negative association between openness and the labor shares of medium and low-skilled workers. Outsourcing, however, primarily affects medium-skilled workers, consistent with the fact that the surveyed firms primarily report to have outsourced IT and other internal services (such as accounting and logistics).
} 
The first column in Table 5 extends our analysis of the effects of openness on the labor share by adding a dummy variable indicating whether the firm has outward FDI or nota variable which is only available for the two cross-sections in 2008 and 2011. Similarly as the foreign ownership dummy, the variable is thought to measure the firm's international mobility of capital, i.e. capital is arguably relatively more mobile in firm's with FDI than in similar firms which do not have FDI. The estimated coefficient is consistent with this hypothesis. The point estimate implies that the labor share of firm's which have FDI is approximately $5.8 \%$ lower than those that do not have. Interestingly, the other openness variables - in particular, the foreign ownership dummy — are not affected by the inclusion of the FDI dummy, suggesting that it captures an additional effect of the firm's international integration above those identified in the baseline model.

In accordance with hypothesis 5 we find consistent evidence that labor's share is decreasing in the mark-up that the firm is able to set over prices. In the second column of Table 5, the mark-up variable is split up into its three components. The regression shows that the number of competitors is positively associated with the labor share. As we hypothesized using findings from recent trade papers, however, the effect of competition depends on whether the firm faces non-price competition or price competition: conditional on the number of competitors, a higher intensity of non-price competition lowers the labor share. This result is consistent with our view that the intensity of non-price competition acts as an indicator of the firm's quality orientation and specialization in niche markets, shielding it from the effect of price competition and allowing it to set a higher mark-up.

Finally, the more wages are set in collectively bargained wage agreements, the higher is the firm's labor share. ${ }^{22}$ Not surprisingly, bargaining coverage is particularly important to increase the labor share for workers with lower skills. ${ }^{23}$

\footnotetext{
${ }^{22}$ In the baseline regression, the coefficient of the coverage rate is identified using variation in coverage rates across three-digit industries within two-digit industries. The estimated coefficient is similar if we use variation across cantons within three-digit industries.

${ }^{23}$ The results for the variables accounting for firm-level demand movements reveal that the firm-level labor share is counter-cyclical. The results thus confirm results from aggregate studies [cf., e.g., Lawless and Whelan, 2011] and imply that the cyclical responsiveness of the denominator (value added) and nominator (labor input) to the business cycle are different. Bentolila and Saint-Paul [2003] explain such a difference with labor hoarding resulting from labor adjustment costs. Adjustment costs imply that the labor share is influenced by (i) past changes in employment and (ii) factors affecting the expected future marginal adjustment costs, among others, perceived uncertainty. Our two demand variables are
} 
Figure 3 illustrates the contribution of the different drivers in accounting for the 0.44 percent decline in the average labor shares of the firms in the estimation sample observed from 2001 to $2010 .^{24}$ The contributions of the various factors are calculated as the change in the respective variable between 2001 and 2010 multiplied by the corresponding regression coefficient. The figure thus illustrates the quantitative importance of the different effects on the labor share arising from the estimated coefficients. The basis for the calculation are the coefficients of Column 2 in Table 3. The main advantage of this regression compared to the baseline model in Column 1 of Table 2 is that it only includes year and industry dummies and hence allows separating the year effect from the effect of changes in the industry composition. Such a decomposition is not possible if we include industry-time and canton-time interactions as we do in the baseline model.

The figure shows that the increased use of ICT - the average of the shares of employees using computer, internet, and intranet grew from $34 \%$ to $46 \%$ - had by far the largest adverse impact on the firm-level labor shares in the sample period. Because the share of wages covered by collective wage agreements declined from 39\% in 2001 to $33 \%$ in 2010, the contribution of changes in the coverage rate on the aggregate labor share is also negative and relatively substantial. The other variables only explain relatively small fractions in the observed change of the labor share over time, mainly because they do not display long-term changes in the period examined.

The figure also illustrates that the main factor accounting for the slight increase in the average firm-level labor share in the period examined is changes in the industry composition, i.e. the number of firms in two-digit industries with above-average labor share increase over time. In fact, several studies show that the sectoral composition has had a negative impact on the labor share in most industrialized countries [Elsby et al., 2013, Arpaia et al., 2009, Serres et al., 2001, Young, 2010]. The finding that Switzerland is different in this respect is part of the explanation for the constancy of the Swiss labor share evidenced in Figure 1 (see Section 7.2).

expected to account for these effects.

${ }^{24}$ The restriction that only the firms in the estimation sample are used does not qualitatively affect the results. However, the fact that the export share declines and hence contributes positively to the change in the labor share is not mirrored in the overall firm sample. There the export share remains constant. 


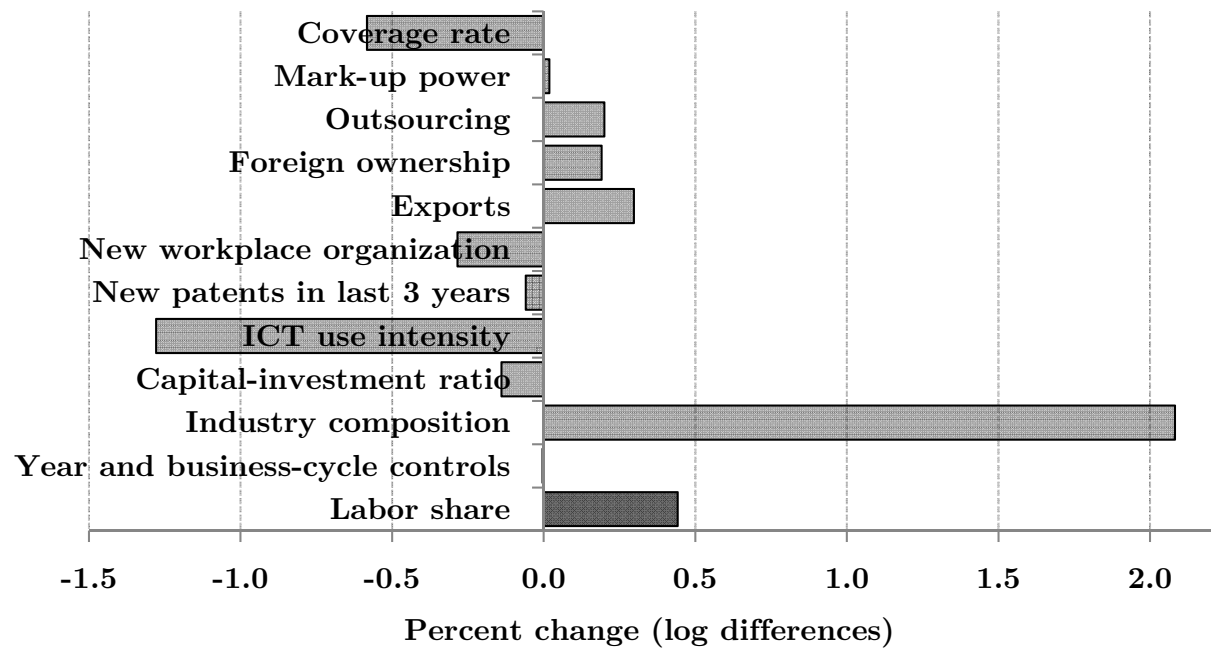

Figure 3: Relative importance of different determinants in accounting for the movements in the average labor share of the firms in the estimation sample 2001-2010

Overall, the firm-level evidence presented in this paper confirm previous findings on more aggregate level. Based on a sample of 11 EU member states and the period 19832002, also the study by the European Commission [2007] identifies technological change as the main driver adversely affecting the labor share. The study also attributes some of the decline in labor shares to the reduction in the bargaining power of labor because of deunionization, while increased openness explains only little in overall changes in the labor share over time. In another related study, the IMF [2007] analyzes potential drivers of the labor share for 18 advanced OECD countries and the period 1982-2002. The study, too, identifies technological change as the main driver for a reduction of the labor share, followed by labor globalization. Total factor productivity, used as measure of technological progress, is also the most important factor explaining declines in labor shares in the study of Hutchinson and Persyn [2012] that is based on cross-country industry-level data from EU-KLEMS. An exception in this respect are the results of Azmat et al. [2012] and Elsby et al. [2013]. The former find a positive correlation between TFP growth on labor shares in network industries, and the latter provide suggestive evidence that the declines in labor shares in US industries are most strongly related to increased import competition. 


\section{Robustness}

This section presents the results of several robustness tests of the results from our preferred specification. ${ }^{25}$ In a first step, we test whether the results are similar across the second (i.e. manufacturing and construction) and the third sector. As shown in Columns 5 and 6 of Table 4, the estimated coefficients are remarkably similar if the sample is split into the two sectors. Indeed, none of the differences in the coefficients is statistically significant. ${ }^{26}$

In a second step, Table 3 tests the robustness of our results with respect to the inclusion of alternative sets of fixed effects. Column 1 presents the outcome of running the baseline specification for the total sample of firms if we do not-as in Table 2exclude firms for which the share of workers in each of the three skill categories is unknown. Column 2 illustrates that not accounting for firm age, firm size, canton-time and industry-time effects but instead controlling for year effects does hardly affect the estimated coefficients for this sample of firms. Similarly, Column 3 augments the baseline specification in Column 1 with industry-time effects on the three-digit level, again with virtually no effect on the estimated coefficients. ${ }^{27}$

Column 4 adds firm fixed effects to the baseline specification, reducing the sample size to 2423 firm-year observations. One notes that many coefficients tend to be less precisely estimated when only exploiting within-firm variation. This is not surprising given the particularly strong inefficiency of FE estimations in our setting (cf. Footnote 13). However, the results suggest that the coefficients of the baseline specification are not biased because we do not account for time-invariant unobserved firm characteristics, since most point estimates of the variables of interest do not show significant changes when including firm fixed effects. The two notable exceptions are the coefficients of the workplace organization variable and the foreign ownership dummy. However, the fact that their coefficients become close to zero is not surprising since there is virtually no within-firm

\footnotetext{
${ }^{25}$ To keep the tables brief, the coefficients of the business cycle controls are not shown.

${ }^{26}$ We tested the coefficients by estimating a model including all firms from both sectors and fully interacting all variables and dummies with an indicator equal to one if the firm belongs to the second sector and zero otherwise. None of the interactions was statically significant for the variables of interest.

${ }^{27}$ The coverage rate needs to be dropped in this specification since it is multicolinear with the set of fixed effects.
} 
variation in the two variables in the estimation sample. ${ }^{28}$

Column 5 disposes of the firm fixed effects but adds the lagged dependent variable to the model instead. Clearly, to the extent that the lagged dependent variable and the covariates do not account for time-invariant unobserved differences between firms, this introduces a Nickell bias to the estimation. If this were the case, not only the estimate of the lagged dependent variable, but also the estimates of covariates that are correlated with the time-invariant part of the error term would be biased. Considering this possibility, it is all the more reassuring that the estimated coefficients in the dynamic specification are remarkably close to the coefficients from the baseline estimation, again indicating that unobserved heterogeneity is not an important concern. ${ }^{29}$ Note also that in this regression, the coefficients of the workplace organization and the foreign ownership variable remain statistically significant and negative.

Column 6 takes a closer look at the question whether our baseline specification suffers from problems due to simultaneity despite our set of variables controlling for the firm's demand situation. We do this by using three-year lagged values of investment, ICT use, the export share, the foreign ownership indicator, the mark-up power and the coverage rate. We do not lag the outsourcing, the workplace organization and the patent variable since they explicitly refer to past firm actions by the way the respective survey question was asked. The results confirm the baseline results and suggest that the baseline specification sufficiently accounts for demand shocks.

In a third step, Table A.3 in the Online Appendix presents the results of adding several potential omitted variables to our main empirical model. These robustness tests confirm that our baseline estimation is robust to the incorporation of heterogeneous labor by adding the $\log$ of the ratio of skilled to unskilled labor in the firm [cf. Arpaia et al., 2009, Hutchinson and Persyn, 2012, Elsby et al., 2013, Karabarbounis and Neiman, 2014], to including the share of R\&D employees, sales growth, and to accounting for variables indicating whether the firm reports to suffer from lack of internal or external funding,

\footnotetext{
${ }^{28}$ The workplace organization variable has few within-firm variation since, as has been mentioned, it is implicitly first-differenced. Another explanation for the low within-firm variation is that the survey question refers to organizational changes implemented in the past five years while the firms are surveyed in three-year intervals. Hence, there could be an overlap between the answers to two consecutive surveys.

${ }^{29}$ The outsourcing variable is no exception. The decrease in this coefficient is not due to the inclusion of the lagged dependent variable but rather due to the different estimation sample.
} 
a potentially relevant variable in the light of the study by Karabarbounis and Neiman [2014].

The last column in Table A.3 includes a binary variable measuring firms' perceptions about shortages of "skilled" labor and labor market regulations for foreign workers (cf. Table 9 in the Online Appendix). We expect that firms that face bigger problems finding suitable workers or suffer more strongly from labor market regulations for foreigners distribute a higher share of income to labor, ceteris paribus. The point estimate of this variable, although not statistically significant, suggests that this might indeed be the case. More importantly, the inclusion does not affect the other results, suggesting that not accounting for labor shortages - which might, for example, increase adoption of labor-saving technologies - does not drive our baseline results.

The fourth step of our robustness analysis is to examine whether the estimates are biased due to the fact that the labor share affects the covariates rather than vice versa. Note that many robustness tests presented above such as adding the lagged dependent variable, firm fixed effects, the variable indicating firms suffering from lack of internal funding, or lagging the explanatory variables already indicate that reverse causality is not driving our results.

However, certain qualitative survey questions enable us to go beyond the tests presented so far. One particularly helpful survey question asked firms to assess the importance of reducing the labor costs share as motive for their innovation activities. Since this survey question pinpoints (innovating) firms for which reverse causality is potentially important, we build an indicator variable which is equal to one for the $36 \%$ of all innovators which answered that reducing the labor cost share is important and zero otherwise. ${ }^{30}$ We then introduce this dummy variable and a full set of interactions with the variables of interest into the baseline specification. We would expect that if there are biases due to reverse causality in our baseline model, we find different coefficients for the subset of firms which aim to reduce their labor shares compared to those which do not.

Table 4 presents the results of this exercise. Column 1 shows the baseline model for the subsample of firms with innovation activities. Column 2 introduces the indicator

\footnotetext{
${ }^{30}$ Firms for which reducing labor cost share is a major concern are identified as those giving at least 4 (of 5) Likert points to the specific survey question.
} 
variable and the interactions with certain variables of interest which are potentially most heavily affected from problems due to reverse causality. ${ }^{31}$ None of these interactions is statistically significant.

Columns 3 and 4 repeat the same exercise using another survey question asking firms with process innovations whether these innovations led to a significant reduction in the average production costs. As labor costs are a substantial fraction of production costs, this survey question also reveals firms which aimed to reduce labor costs and hence possibly the labor share. Its main advantage compared to the survey question used before is the larger sample size. As can be seen in Column 4, the interaction terms are again statistically insignificant. These regressions hence suggests that the quantitative relevance of reverse causality is limited in our specification.

\section{$7 \quad$ Extensions}

\subsection{Share of female employees}

As a an extension to the preceding results, this section looks at the question whether the female share in the firm's workforce affect the firm's labor share. This analysis is motivated by the possibility that women earn less even when being equally productive as men. Indeed, Hellerstein et al. [2002] propose to test for the presence of gender wage discrimination by including the female share as an explanatory variable in regressions closely related to the labor share regressions presented in this paper. Note that there are several explanations why a gender pay gap might arise. ${ }^{32}$ However, the source of the gender wage gap is not important for our purpose - what is of interest to us is whether a rising female share comes at the expense of the income share accruing to labor.

We find consistent evidence in favor of this hypothesis, i.e. the (logarithmic) female share among the full-time equivalent employees in the firm is negatively related to the share of value added that firms distribute to labor. Table 5 demonstrates the statistical

\footnotetext{
${ }^{31}$ We chose to present only the interactions with this subset of variables to keep the table sufficiently brief. There are, however, no statistically significant differences between the two subsamples in an estimation in which all variables of interest are interacted with the indicator variable.

${ }^{32}$ The literature broadly stresses two different explanations for the gap. The first highlights discriminatory tastes of employers. The second strand of the literature stresses social norms and gender differences in negotiating over wages [cf. Bertrand, 2011, for on overview].
} 
significance and the robustness of this association. It holds when controlling for a wide set of firm observables (Column 3), is robust to additionally including firm fixed effects which account, among others, for potential differential sorting of male and female employees to firms with different time-invariant unobservables (Column 4), and it holds if we only look at firms for which reducing labor costs is not an important innovation motive (Column $5)$, or if we lag the female share (not shown). ${ }^{33}$

Although the above regressions control for variable inputs, constant and several timevarying firm-level controls, it is unclear whether our female share variable captures the effect of the gender wage gap or whether it is driven by unobserved time-varying third factors such as changes in tastes of managers, which in turn also relate to firm-level labor shares. Ruling out such omitted variable biases requires exogenous movements in firmlevel female employee shares which we do not have. However, based on the findings of a previous study we can at least find indicative evidence in this direction. Lalive and Stutzer [2010] show that the net gender wage gap is significantly smaller in Swiss regions where a larger fraction of the citizenry has voted in favor of equal pay in a popular initiative of 1981. This popular initiative proposed amending the Swiss constitution by an article concerning equal pay of men and women.

Accordingly, if our female share variable properly captures the gender wage gap effect, the negative relationship between the female employment share and the labor share should be larger in the subsample of firms that are located in cantons in which the initiative did not reach at least $50 \%$ approval. Column 6 of Table 5 shows the result of re-estimating the FE regression of Column 4 for this specific subsample. As can be seen, the point estimate in the restricted sample is in fact larger, suggesting a more negative effect of increasing female employment on the labor share in those cantons. Accordingly, the female share variable seems to capture the expected gender wage effect properly.

The estimated point estimates also provides evidence that the coefficient in fact captures the effect of the gender pay gap. The estimate in Column 3 implies that a firm

\footnotetext{
${ }^{33}$ Since the variable is expressed in full-time equivalents, firm-specific changes in part-time employment should not affect the result. As a robustness check, we included the share of female employees and controlled for the share of part-time employees in the firm. The results are very similar to those presented here. Moreover, including the labor shortage variable or any other covariates included in the last and in the next section has no major effect on the results.
} 
with 10 employees of which 5 are female that hires an additional female employee (hence increasing the female share by $20 \%$ ) could reduce its labor share by $0.64 \%$. In fact, this implies that the newly hired female employee earns $6.4 \%$ less than the previously employed male employee. This point estimate as well as the others presented in the table are hence within the array of the estimates of the "unexplained" gender pay gap in Switzerland, typically ranging from 7 to $15 \%$ depending on the method [Bonjour and Gerfin, 2001, Lalive and Stutzer, 2010, OECD, 2013b]. Thus, a provocative interpretation of the coefficients is that receivers of capital income - rather than the male co-workers of women - extract the main part of the gains arising from the gender wage gap. ${ }^{34}$

\subsection{The constancy of the Swiss labor share}

What explains the observed constancy of the labor share in Switzerland? Considering the results presented in this paper, there are in our view four potential explanations.

The first explanation is evident from Figure 3: an important factor is that the sectoral composition shifts in such a way that the aggregate labor share is increased-or, at least, not decreased. ${ }^{35}$ The fact that the sectoral composition did not adversely affect Switzerland's labor share in the past stands in contrast to the shifts towards industries with low labor shares observed in most other developed countries [Elsby et al., 2013, Arpaia et al., 2009, Serres et al., 2001, Young, 2010]. Switzerland's specialty in this respect may be explained by its comparative advantages. In particular, Swiss exporters have focused on niche products and services with high quality, above-average complexity and relatively high skill intensity [Siegenthaler, Forthcoming, OECD, 2013b]. Therefore, losses in value added shares of traditional labor-intensive industries (such as construction or manufacturing of raw materials or textiles) and value added gains in industries with low labor shares (e.g. finance, ICT, chemical or pharmaceutical industry, or water and electricity supply) are compensated by shifts towards skill-intensive industries with above-

\footnotetext{
${ }^{34}$ The estimated coefficients are also in the range of those presented in previous studies examining the relationship between female shares and firm's profitability in the attempt to prove the presence of gender wage discrimination on the labor market. See, for example, Vandenberghe [2011, Table 3], which also estimates labor share equations for Belgian plants, or Hellerstein et al. [2002, Table 2, Column 4] which present profit share equations for a sample of US firms.

${ }^{35}$ Table A.2 provides another illustration of this fact. It shows that the average firm-level labor share does not depend on the age of a specific firm, i.e. the labor share of young firms is very similar to the labor share of older firms.
} 
average labor shares (e.g., electrical and watchmaking industry, and business services such as accounting, consultancy, or R\&D). ${ }^{36}$

A second potential explanation of the relative constancy of the Swiss labor share is that Switzerland went through enduring shortages of labor, limiting the outside options of firms when bargaining over wages with the desired workers. In particular, throughout the post-war period until the early 1990s, Switzerland had a very low unemployment rate that lay almost always below $2 \%$, coupled with a high employment rate. As aggregate unemployment rose in the course of the stagnation phase of the 1990s, a strong shift in labor demand towards high-skilled workers again resulted in shortages of skilled workers in the recovery years after 1997 [Puhani, 2003, 2005].

A third potential reason for the relative constancy of the Swiss labor share is the comparatively slow adoption of ICT throughout the 1980s and the early 1990s. Figure 4 illustrates that Switzerland's growth of ICT capital was substantially lower between 1984-1997 than the growth observed in many other developed countries. The comparatively low growth in ICT capital are mirrored in low rates of technological progress, be it in terms of direct measures of productivity growth (labor productivity and total factor productivity [Siegenthaler, Forthcoming, OECD, 2013a]) or indicators of technological progress such as per capita patents, the R\&D investment share, or the share of ICT employment in business sector employment [OECD, 2011]. The negative impetus of technological progress in general and ICT adoption in particular on the labor share was hence potentially smaller in Switzerland than in most other developed countries, particularly before 1997 .

\footnotetext{
${ }^{36}$ The specialization in knowledge-based services and innovative manufacturing is indeed likely to be the result of the relatively high unit labor costs in Switzerland, rendering price competition with foreign competitors difficult. Moreover, since Switzerland relative high unit labor costs were comparatively high throughout most of the post-war era, Switzerland never had a large share of firms engaging in pricesensitive labor-intensive mass production which became subject to import competition from low-income countries in the course of the last 30 years.
} 
Figure 4: Contribution of ICT equipment to growth of total capital services in selected OECD countries $(1984=100)$ Source: OECD productivity database

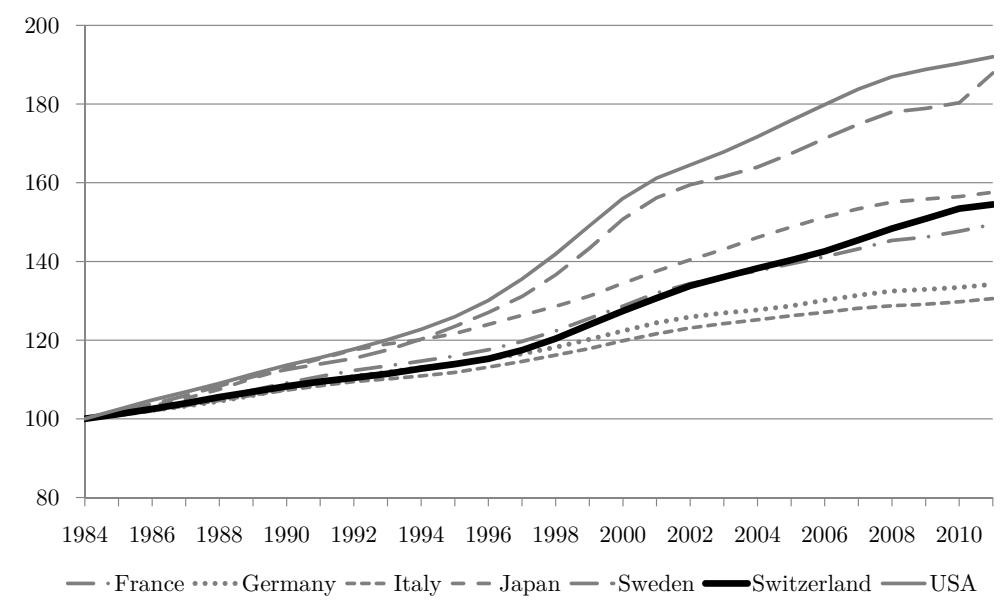

A fourth potential explanation for the relative constancy of the labor share could be that Switzerland's workforce has comparatively high human capital. ${ }^{37}$ As a result of the VET system, Switzerland's comparative advantage pertaining to human capital might be specifically prevalent pertaining to job-related skills. As higher (job-related) skills increase the fraction of the population complementary to (ICT) capital and technological progress, Switzerland's labor force may have been on average less substituted by capital and technology than was the case in other developed countries, leading to a smaller decline in the labor share through technological progress. This explanation is also consistent with the comparatively little rise in wage inequality in Switzerland in the last decades.

\section{Conclusions}

This paper examines the determinants of the labor share in a representative panel of Swiss firms for the period 2001-2010. Due to the use of firm-level data, we are able to address more thoroughly than previous papers whether the estimated regressions are affected by composition biases or endogeneity problems such as omitted variables and reverse causality.

We identify the use of computers and internet in the firm as the main factor leading to

\footnotetext{
${ }^{37}$ As the OECD [2013b] writes: "Switzerland has a comparative advantage in human capital, and performs very well by OECD standards, both in terms of overall education participation and outcomes".
} 
reductions in labor's share of income in the sample period. Our regressions also show robust across-firm evidence that the labor share is negatively related to the firm's openness and the firm's mark-up power, while being positively associated with collective bargaining coverage. Finally, we demonstrate that the labor share declines in the use of measures of new workplace organization (i.e. increased job rotation and more decentralized workplace organization) and it declines in the firm's share of female employees.

The paper also addresses why Switzerland stands out as one of the very few developed countries in which the labor share has remained practically stable. We provide four explanations: no structural shifts towards industries with below-average labor shares as it is observed in other developed countries; enduring labor shortages; a slow extension of ICT capital mirrored in slow technological progress; and a comparatively skilled workforce.

What can be said about the future development of the labor share? In line with more aggregate studies that identified a negative association between technological progress (i.e. TFP growth) and the labor share, we identified the within-firm use of ICT as the main driver of a decline in the labor share. Does this imply that reductions in the labor share will continue as long as the use of ICT continues to spread in firms? No, it does not. As our skill-group specific regression suggest, the effect of ICT use on the labor share depends on the question whether the "average worker" is complementary to ICT or not. Figure 5 illustrates this. It shows how the average ICT skills of the working age population in a country relate to trends in the labor share within these countries. More specifically, the figure plots the percentage point change of the adjusted average labor share in several developed countries from 1993-1995 to 2010-2012 against the ICT skills of its population aged 15-64. ICT skills are measured as the average (standardized) results of the PIAAC test in problem solving in technology-rich environments[see Hanushek et al., 2013, for more details on the test]. Unfortunately, Switzerland did not participate in the test.

The figure shows that countries in which the share of the population that has medium or high ICT skills is above the cross-country average have experienced smaller reductions in labor shares than countries in which this fraction is small. The correlation is 0.45 . This correlation is higher than the correlation between labor share changes and the average numeracy and literacy skills of the 15-64 year-olds from the PIAAC test, suggesting that 
ICT skills matter more than general skills. ${ }^{38}$ More generally, the figure suggests that education policy, by raising job-related human capital, might be key for policy makers aiming at limiting the trend decline in labor shares.

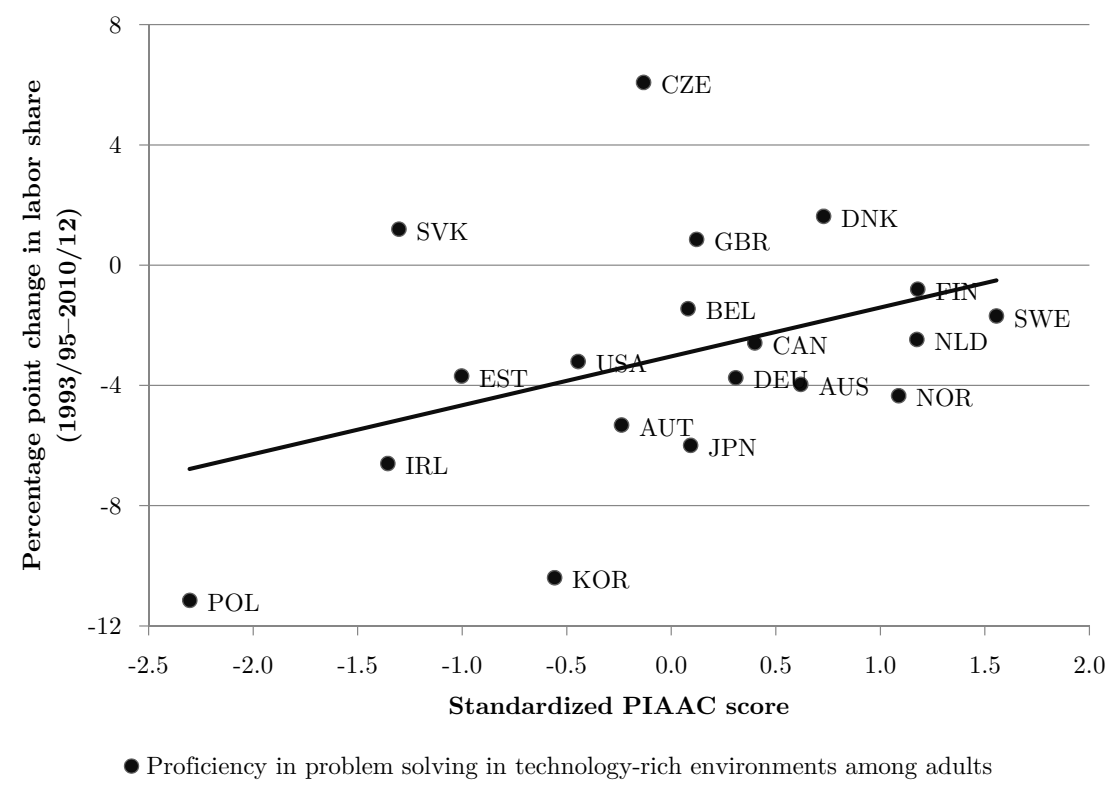

Figure 5: The role of the average worker's skills: absolute change in labor share 1993/952010/12 and ICT skills among adults

\section{References}

Daron Acemoglu. Labor- and capital-augmenting technical change. Journal of the European Economic Association, 1(1):1-37, 2003.

Daron Acemoglu and David Autor. Handbook of Labor Economics, volume 4b, chapter Skills, tasks and technologies: implications for employment and earnings, pages 10431171. Elsevier, 2011.

Pol Antràs. Is the U.S. aggregate production function Cobb-Douglas? new estimates of the elasticity of substitution. Contributions in Macroeconomics, 4(1), 2004.

\footnotetext{
${ }^{38}$ The correlation holds if we exclude certain outliers (such as Poland) and also appears for the subsample of 13 countries for which we have PIAAC test results and adjusted labor shares from 1980 to 2012. In this latter case, the correlation is 0.4 . The correlation between the average numeracy and literacy test scores and labor share changes is 0.3 and 0.1 , respectively.
} 
Alfonso Arpaia, Esther Pérez, and Karl Pichelmann. Understanding labour income share dynamics in europe. Technical report, MPRA Economic Papers 379, 2009.

Anthony B. Atkinson. Factor shares: the principal problem of political economy? Oxford Review of Economic Policy, 25(1):3-16, 2009.

Ghazala Azmat, Alan Manning, and John Van Reenen. Privatization and the decline of labour's share: International evidence from network industries. Economica, 79(315): 470-492, 2012.

Richard Baldwin and James Harrigan. Zeros, quality, and space: trade theory and trade evidence. American Economic Journal: Microeconomics, 3(2):60-88, 2011.

Samuel Bentolila and Gilles Saint-Paul. Explaining movements in the labor share. Contributions to Macroeconomics, 3(1):1-31, 2003.

Marianne Bertrand. Handbook of Labor Economics, chapter New perspectives on gender, pages 1543-1590. Elsevier, 2011.

Olivier Blanchard and Francesco Giavazzi. Macroeconomic effects of regulation and deregulation in goods and labor markets. The Quarterly Journal of Economics, 118(3): 879-907, 2003.

Dorothe Bonjour and Michael Gerfin. The unequal distribution of unequal pay: An empirical analysis of the gender wage gap in Switzerland. Empirical Economics, 26(2): 407-427, 2001.

Timothy F. Bresnahan, Erik Brynjolfsson, and Lorin M. Hitt. Information technology, workplace organization, and the demand for skilled labor: firm-level evidence. The Quarterly Journal of Economics, 117(1):339-376, 2002.

Eve Caroli and John Van Reenen. Skill-biased organizational change? Evidence from a panel of British and French establishments. The Quarterly Journal of Economics, 116 (4):1449-1492, 2001.

Daniele Chechi and Cecilia García-Peñalosa. Labour market institutions and the personal distribution of income in the OECD. Economica, 77(307):413-450, 2010. 
Michael W. L. Elsby, Bart Hobijn, and Aysegül Sahin. The decline of the U.S. labor share. Technical report, Economic Studies at Brookings, 2013.

European Commission. Employment in Europe 2007, chapter The labour income share in the European Union, pages 237-272. Office for Offical Publications of the European Communities, Luxembourg, 2007.

Robert C. Feenstra and Gordon H. Hanson. The impact of outsourcing and hightechnology capital on wages: estimates for the United States, 1979-1990. The Quarterly Journal of Economics, 114(3):907-940, 1999.

Andrew Glyn. The Oxford handbook of economic inequality, chapter Functional distribution and income inequality, pages 101-126. Oxford University Press, New York, 2009.

Douglas Gollin. Getting income shares right. Journal of Political Economy, 110(2): 458-474, 2002.

Eric A. Hanushek, Guido Schwerdt, Simon Wiederhold, and Ludger Woessmann. Returns to skills around the evidence from PIAAC. NBER Working Paper 19762, 2013.

Judith K. Hellerstein, David Neumark, and Kenneth R. Troske. Market forces and sex discrimination. The Journal of Human Resources, 37(2):353-380, 2002.

Heinz Hollenstein and Tobias Stucki. The 'new firm paradigm' and the provision of training: the impact of ICT, workplace organization and human capital. Swiss Journal of Economics and Statistics, 148(4):557-595, 2012.

John Hutchinson and Damiaan Persyn. Globalisation, concentration and footloose firms: in search of the main cause of the declining labour share. Review of World Economics, 148(1):17-43, 2012.

IMF. World Economic Outlook, volume April, chapter The globalization of labor, pages 161-192. IMF, Washington, 2007.

Arjun Jayadev. Capital account openness and the labour share of income. Cambridge Journal of Economics, 31(3):423-443, 2007. 
Michal Kalecki. Selected essays on the dynamics of the capitalist economy. Cambridge University Press, Cambridge, 1971.

Loukas Karabarbounis and Brent Neiman. The global decline of the labor share. Quarterly Journal of Economics, 129(1):61-103, 2014.

Alan B. Krueger. Measuring labor's share. The American Economic Review, 89(2):45-51, 1999.

Rafael Lalive and Alois Stutzer. Approval of equal rights and gender differences in wellbeing. Journal of Population Economics, 23(3):933-962, 2010.

Martina Lawless and Karl T. Whelan. Understanding the dynamics of labor shares and inflation. Journal of Macroeconomics, 33(2):121-136, 2011.

James Levinsohn and Amil Petrin. Estimating production functions uing inputs to control for unobservables. The Review of Economic Studies, 70(2):317-341, 2003.

Assar Lindbeck and Dennis J. Snower. Multitask learning and the reorganization of work: from Tayloristic to holistic organization. Journal of Labor Economics, 18(3):353-376, 2000 .

Ian M. McDonald and Robert M. Solow. Wage bargaining and employment. The American Economic Review, 71(5):896-908, 1981.

Guy Michaels, Ashwini Natraj, and John Van Reenen. Has ICT polarized skill demand? evidence from eleven countries over 25 years. The Review of Economics and Statistics, Forthcoming, 2013.

OECD. Divided we stand: Why inequality keeps rising. OECD Publishing, 2011.

OECD. OECD compendium of productivity indicators 2012. OECD Publishing, 2013a.

OECD. OECD Economic Surveys: Switzerland 2013. OECD Publishing, 2013b.

Mariacristina Piva, Enrico Santarelli, and Marco Vivarelli. The skill bias effect of technological and organisational change: Evidence and policy implications. Research Policy, 34(2):141-157, 2005. 
Patrick A. Puhani. The rise and fall of Swiss unemployment: relative demand shocks, wage rigidities, and temporary immigrants. IZA Discussion Papers 684, Institute for the Study of Labor (IZA), 2003.

Patrick A. Puhani. Relative supply and demand for skills in Switzerland. Swiss Journal of Economics and Statistics, 141(4):555-584, 2005.

Alain De Serres, Stefano Scarpetta, and Christine De La Maisonneuve. Falling wage shares in Europe and the United States: How important is aggregation bias? Empirica, $28: 375-401,2001$.

Michael Siegenthaler. Has switzerland really been marked by low productivity growth? hours worked and labor productivity in switzerland in a long-run perspective. Review of Income and Wealth, Forthcoming.

Robert M. Solow. A skeptical note on the constancy of relative shares. The American Economic Review, 48(4):618-631, 1958.

Vincent Vandenberghe. Firm-level evidence on gender wage discrimination in the Belgian private economy. Labour, 25(3):330-349, 2011.

Eric A. Verhoogen. Trade, quality upgrading, and wage inequality in the Mexican manufacturing sector. The Quarterly Journal of Economics, 123(2):489-530, 2008.

Aidan Vining and Steven Globerman. A conceptual framework for understanding the outsourcing decision. European Management Journal, 17(6):645-654, 1999.

Andrew T. Young. One of the things we know that ain't so: Is US labor's share relatively stable? Journal of Macroeconomics, 32(1):90-102, 2010. 


\section{$9 \quad$ Appendix}

Table 1: Descriptive statistics

\begin{tabular}{lcccc}
\hline \multicolumn{1}{c}{ Variable } & Mean & Std. Dev. & Min. & Max. \\
\hline Labor share & 0.6 & 0.19 & 0.01 & 1 \\
Investment-output ratio (ln) & -2.98 & 1.31 & -13.62 & 4.69 \\
ICT use intensity & 0.42 & 0.28 & 0 & 0.9 \\
New patents in last 3 years & 0.02 & 0.28 & 0 & 13.5 \\
New workplace organization & 0.01 & 0.65 & -1.96 & 2.02 \\
Export share & 0.27 & 0.35 & 0 & 1 \\
Foreign ownership & 0.19 & 0.39 & 0 & 1 \\
Outsourcing of tasks & 0.57 & 0.96 & 0 & 5 \\
Mark-up power & 0.16 & 1.78 & -4.93 & 6.17 \\
Coverage rate & -1.4 & 1.06 & -10.72 & 0 \\
Past demand development & 3.37 & 1.02 & 1 & 5 \\
Expected demand development & 3.16 & 0.85 & 1 & 5 \\
Intermediate inputs & -0.37 & 1.09 & -4.60 & 3.89 \\
Intermediate inputs squared & 1.33 & 2.62 & 0 & 21.12 \\
\multicolumn{1}{c}{$\mathrm{N}$} & & 3926 & & \\
\hline
\end{tabular}


Table 2: Preferred specification (OLS and SUR estimations)

\begin{tabular}{|c|c|c|c|c|}
\hline VARIABLES & $\begin{array}{c}(1) \\
\text { POLS }\end{array}$ & $\begin{array}{c}(2) \\
\text { High-skilled } \\
\text { labor share }\end{array}$ & $\begin{array}{c}(3) \\
\text { Medium-skilled } \\
\text { labor share }\end{array}$ & $\begin{array}{c}(4) \\
\text { Low-skilled } \\
\text { labor share }\end{array}$ \\
\hline & & \multicolumn{3}{|c|}{ Fraction of total labor share } \\
\hline Production technology & & $26.5 \%$ & $45.3 \%$ & $28.2 \%$ \\
\hline Investment-output ratio & $\begin{array}{c}0.016 * * \\
(0.007)\end{array}$ & $\begin{array}{c}0.006 \\
(0.012)\end{array}$ & $\begin{array}{c}0.014 \\
(0.010)\end{array}$ & $\begin{array}{c}0.084^{* *} \\
(0.014)\end{array}$ \\
\hline ICT use intensity & $\begin{array}{c}-0.144^{* *} \\
(0.036)\end{array}$ & $\begin{array}{c}0.715^{* *} \\
(0.071)\end{array}$ & $\begin{array}{c}0.030 \\
(0.057)\end{array}$ & $\begin{array}{c}-1.308^{* *} \\
(0.082)\end{array}$ \\
\hline New patents in last 3 years & $\begin{array}{c}-0.037^{* *} \\
(0.018)\end{array}$ & $\begin{array}{c}0.003 \\
(0.024)\end{array}$ & $\begin{array}{c}-0.071^{* *} \\
(0.027)\end{array}$ & $\begin{array}{c}-0.170 * * \\
(0.028)\end{array}$ \\
\hline New workplace organization & $\begin{array}{c}-0.023^{* *} \\
(0.011)\end{array}$ & $\begin{array}{c}0.130 * * \\
(0.023)\end{array}$ & $\begin{array}{l}-0.024 \\
(0.020)\end{array}$ & $\begin{array}{c}-0.134^{* *} \\
(0.026)\end{array}$ \\
\hline \multicolumn{5}{|l|}{ Openness } \\
\hline Export share & $\begin{array}{c}-0.076^{* *} \\
(0.027)\end{array}$ & $\begin{array}{c}0.286 * * \\
(0.050)\end{array}$ & $\begin{array}{c}-0.308^{* *} \\
(0.047)\end{array}$ & $\begin{array}{c}-0.107^{*} \\
(0.063)\end{array}$ \\
\hline Foreign ownership & $\begin{array}{c}-0.054^{* *} \\
(0.020)\end{array}$ & $\begin{array}{c}-0.074^{*} \\
(0.038)\end{array}$ & $\begin{array}{l}-0.050 \\
(0.033)\end{array}$ & $\begin{array}{c}-0.126^{* *} \\
(0.048)\end{array}$ \\
\hline Outsourcing of tasks & $\begin{array}{c}-0.015^{* *} \\
(0.007)\end{array}$ & $\begin{array}{c}0.011 \\
(0.012)\end{array}$ & $\begin{array}{c}-0.039 * * \\
(0.012)\end{array}$ & $\begin{array}{c}0.011 \\
(0.016)\end{array}$ \\
\hline \multicolumn{5}{|l|}{ Institutions } \\
\hline Mark-up power & $\begin{array}{c}-0.013^{* *} \\
(0.004)\end{array}$ & $\begin{array}{c}0.001 \\
(0.008)\end{array}$ & $\begin{array}{c}-0.016^{* *} \\
(0.007)\end{array}$ & $\begin{array}{c}-0.039 * * \\
(0.009)\end{array}$ \\
\hline Coverage rate & $\begin{array}{c}0.024^{* *} \\
(0.009)\end{array}$ & $\begin{array}{c}0.004 \\
(0.016)\end{array}$ & $\begin{array}{l}0.027^{*} \\
(0.014)\end{array}$ & $\begin{array}{l}0.033^{*} \\
(0.018)\end{array}$ \\
\hline \multicolumn{5}{|l|}{ Business cycle } \\
\hline Past demand development & $\begin{array}{c}-0.025^{* *} \\
(0.007)\end{array}$ & $\begin{array}{c}-0.027^{* *} \\
(0.014)\end{array}$ & $\begin{array}{c}-0.022^{*} \\
(0.012)\end{array}$ & $\begin{array}{c}-0.032^{* *} \\
(0.016)\end{array}$ \\
\hline Expected demand development & $\begin{array}{c}0.010 \\
(0.009)\end{array}$ & $\begin{array}{c}0.022 \\
(0.017)\end{array}$ & $\begin{array}{c}0.022 \\
(0.014)\end{array}$ & $\begin{array}{l}-0.023 \\
(0.018)\end{array}$ \\
\hline Intermediate inputs & $\begin{array}{c}0.081^{* *} \\
(0.011)\end{array}$ & $\begin{array}{c}0.082^{* *} \\
(0.019)\end{array}$ & $\begin{array}{c}0.094^{* *} \\
(0.017)\end{array}$ & $\begin{array}{l}0.042^{*} \\
(0.023)\end{array}$ \\
\hline Intermediate inputs squared & $\begin{array}{c}-0.011^{*} \\
(0.006)\end{array}$ & $\begin{array}{l}-0.016^{*} \\
(0.009)\end{array}$ & $\begin{array}{c}-0.021^{* *} \\
(0.008)\end{array}$ & $\begin{array}{l}-0.012 \\
(0.010)\end{array}$ \\
\hline $\begin{array}{l}\text { Observations } \\
R^{2}\end{array}$ & $\begin{array}{l}3,706 \\
0.293\end{array}$ & 3,706 & 3,706 & 3,706 \\
\hline Firm size and age controls & Yes & Yes & Yes & Yes \\
\hline Industry-year dummies & Yes & Yes & Yes & Yes \\
\hline Canton-year dummies & Yes & Yes & Yes & Yes \\
\hline
\end{tabular}

Robust standard errors in parentheses

** $\mathrm{p}<0.05, * \mathrm{p}<0.1$ 
Table 3: Robustness of main specification

\begin{tabular}{|c|c|c|c|c|c|c|}
\hline VARIABLES & $\begin{array}{c}(1) \\
\text { Base- } \\
\text { line } \\
\end{array}$ & $\begin{array}{c}(2) \\
\text { POLS } \\
\text { Total } \\
\end{array}$ & $\begin{array}{c}(3) \\
\text { POLS } \\
\text { Total } \\
\end{array}$ & $\begin{array}{c}(4) \\
\text { FE } \\
\text { Limited }\end{array}$ & $\begin{array}{c}(5) \\
\text { Dynamic } \\
\text { OLS }\end{array}$ & $\begin{array}{c}\text { (6) } \\
\text { POLS } \\
\text { Lagged val. }\end{array}$ \\
\hline \multicolumn{7}{|l|}{ Production technology } \\
\hline Investment-output ratio & $\begin{array}{c}0.018 * * \\
(0.007)\end{array}$ & $\begin{array}{c}0.016^{* *} \\
(0.006)\end{array}$ & $\begin{array}{c}0.017^{* *} \\
(0.007)\end{array}$ & $\begin{array}{c}0.016^{* *} \\
(0.007)\end{array}$ & $\begin{array}{c}0.019 * * \\
(0.007)\end{array}$ & $\begin{array}{c}0.018^{* *} \\
(0.009)\end{array}$ \\
\hline ICT use intensity & $\begin{array}{c}-0.128^{* *} \\
(0.035)\end{array}$ & $\begin{array}{c}-0.114^{* *} \\
(0.034)\end{array}$ & $\begin{array}{c}-0.124^{* *} \\
(0.036)\end{array}$ & $\begin{array}{c}-0.082^{*} \\
(0.046)\end{array}$ & $\begin{array}{c}-0.072^{* *} \\
(0.034)\end{array}$ & $\begin{array}{l}-0.086 \\
(0.053)\end{array}$ \\
\hline New patents in last 3 years & $\begin{array}{c}-0.026^{* *} \\
(0.012)\end{array}$ & $\begin{array}{c}-0.028^{* *} \\
(0.011)\end{array}$ & $\begin{array}{l}-0.029 \\
(0.017)\end{array}$ & $\begin{array}{l}-0.017 \\
(0.015)\end{array}$ & $\begin{array}{c}-0.028^{* *} \\
(0.012)\end{array}$ & $\begin{array}{l}-0.014 \\
(0.012)\end{array}$ \\
\hline New workplace organization & $\begin{array}{c}-0.027^{* *} \\
(0.011)\end{array}$ & $\begin{array}{c}-0.027^{* *} \\
(0.010)\end{array}$ & $\begin{array}{c}-0.021^{*} \\
(0.011)\end{array}$ & $\begin{array}{l}-0.005 \\
(0.011)\end{array}$ & $\begin{array}{c}-0.032^{* *} \\
(0.011)\end{array}$ & $\begin{array}{l}-0.027 \\
(0.018)\end{array}$ \\
\hline \multicolumn{7}{|l|}{ Openness } \\
\hline Export share & $\begin{array}{c}-0.079 * * \\
(0.027)\end{array}$ & $\begin{array}{c}-0.085^{* *} \\
(0.025)\end{array}$ & $\begin{array}{c}-0.098^{* *} \\
(0.028)\end{array}$ & $\begin{array}{c}-0.118^{* *} \\
(0.057)\end{array}$ & $\begin{array}{l}-0.032 \\
(0.027)\end{array}$ & $\begin{array}{c}-0.073^{*} \\
(0.042)\end{array}$ \\
\hline Foreign ownership & $\begin{array}{c}-0.056^{* *} \\
(0.020)\end{array}$ & $\begin{array}{c}-0.053^{* *} \\
(0.019)\end{array}$ & $\begin{array}{c}-0.075^{* *} \\
(0.020)\end{array}$ & $\begin{array}{l}-0.004 \\
(0.028)\end{array}$ & $\begin{array}{c}-0.059^{* *} \\
(0.020)\end{array}$ & $\begin{array}{c}-0.092^{* *} \\
(0.031)\end{array}$ \\
\hline Outsourcing of tasks & $\begin{array}{c}-0.017^{* *} \\
(0.007)\end{array}$ & $\begin{array}{c}-0.017^{* *} \\
(0.006)\end{array}$ & $\begin{array}{c}-0.013^{*} \\
(0.007)\end{array}$ & $\begin{array}{l}-0.010 \\
(0.006)\end{array}$ & $\begin{array}{c}-0.004 \\
(0.007)\end{array}$ & $\begin{array}{c}-0.028^{* *} \\
(0.011)\end{array}$ \\
\hline \multicolumn{7}{|l|}{ Institutions } \\
\hline Mark-up power & $\begin{array}{c}-0.012^{* *} \\
(0.004)\end{array}$ & $\begin{array}{c}-0.011^{* *} \\
(0.004)\end{array}$ & $\begin{array}{c}-0.011^{* *} \\
(0.004)\end{array}$ & $\begin{array}{l}-0.008 \\
(0.005)\end{array}$ & $\begin{array}{c}-0.011^{* *} \\
(0.004)\end{array}$ & $\begin{array}{c}-0.012^{*} \\
(0.006)\end{array}$ \\
\hline Coverage rate & $\begin{array}{c}0.031^{* *} \\
(0.009)\end{array}$ & $\begin{array}{c}0.027^{* *} \\
(0.009)\end{array}$ & & $\begin{array}{c}0.010 \\
(0.012)\end{array}$ & $\begin{array}{l}0.016^{*} \\
(0.009)\end{array}$ & $\begin{array}{c}0.034^{* *} \\
(0.013)\end{array}$ \\
\hline Lagged labor share & & & & & $\begin{array}{c}0.442^{* *} \\
(0.036)\end{array}$ & \\
\hline Observations & 3,926 & 3,926 & 3,926 & 3,926 & 2,512 & 1,639 \\
\hline$R^{2}$ & 0.294 & 0.248 & 0.395 & 0.441 & 0.426 & 0.284 \\
\hline Business cycle controls & Yes & Yes & Yes & Yes & Yes & Yes \\
\hline Firm size and age controls & Yes & No & Yes & Yes & Yes & Yes \\
\hline Year dummies & No & Yes & No & No & No & No \\
\hline Industry dummies & No & Yes & No & No & No & No \\
\hline Industry-year dummies & Yes & No & Yes+ & Yes & Yes & Yes \\
\hline Canton dummies & No & No & No & No & No & No \\
\hline Canton-year dummies & Yes & No & Yes & No & Yes & Yes \\
\hline Firm dummies & No & No & No & Yes & No & No \\
\hline
\end{tabular}

Robust standard errors in parentheses

$$
* * \mathrm{p}<0.05, * \mathrm{p}<0.1
$$

+ Estimations in Column 3 include 3-digit instead of 2-digit industry-year dummies 
Table 4: Subsample analysis

\begin{tabular}{|c|c|c|c|c|c|c|}
\hline VARIABLES & $\begin{array}{c}\text { (1) } \\
\text { Selected } \\
\text { innovators }\end{array}$ & $\begin{array}{c}(2) \\
\text { Selected } \\
\text { innovators } \\
\end{array}$ & $\begin{array}{c}(3) \\
\text { Process } \\
\text { innovators } \\
\end{array}$ & $\begin{array}{c}(4) \\
\text { Process } \\
\text { innovators } \\
\end{array}$ & $\begin{array}{c}\text { (5) } \\
\text { Industry }\end{array}$ & $\begin{array}{c}\text { (6) } \\
\text { Services } \\
\end{array}$ \\
\hline Indicator & & $\begin{array}{c}-0.039 \\
(0.077)\end{array}$ & & $\begin{array}{l}-0.032 \\
(0.058)\end{array}$ & & \\
\hline Indicator $\mathrm{x}$ Investment-output ratio & & $\begin{array}{c}-0.024 \\
(0.022)\end{array}$ & & $\begin{array}{c}0.005 \\
(0.016)\end{array}$ & & \\
\hline Indicator $\mathrm{x}$ ICT use intensity & & $\begin{array}{c}0.059 \\
(0.103)\end{array}$ & & $\begin{array}{c}0.066 \\
(0.074)\end{array}$ & & \\
\hline Indicator $\mathrm{x}$ Workplace organization & & $\begin{array}{c}-0.034 \\
(0.039)\end{array}$ & & $\begin{array}{l}-0.018 \\
(0.029)\end{array}$ & & \\
\hline Indicator x Outsourcing & & $\begin{array}{c}0.006 \\
(0.021)\end{array}$ & & $\begin{array}{l}-0.002 \\
(0.016)\end{array}$ & & \\
\hline \multicolumn{7}{|l|}{ Production technology } \\
\hline Investment-output ratio & $\begin{array}{c}0.037^{* *} \\
(0.011)\end{array}$ & $\begin{array}{c}0.046^{* *} \\
(0.013)\end{array}$ & $\begin{array}{c}0.024^{* *} \\
(0.009)\end{array}$ & $\begin{array}{l}0.022^{*} \\
(0.011)\end{array}$ & $\begin{array}{c}0.008 \\
(0.007)\end{array}$ & $\begin{array}{c}0.032^{* *} \\
(0.013)\end{array}$ \\
\hline ICT use intensity & $\begin{array}{c}-0.143^{* *} \\
(0.058)\end{array}$ & $\begin{array}{c}-0.154^{* *} \\
(0.073)\end{array}$ & $\begin{array}{c}-0.127^{* *} \\
(0.047)\end{array}$ & $\begin{array}{c}-0.157^{* *} \\
(0.055)\end{array}$ & $\begin{array}{c}-0.147^{* *} \\
(0.042)\end{array}$ & $\begin{array}{c}-0.133^{* *} \\
(0.060)\end{array}$ \\
\hline New patents in last 3 years & $\begin{array}{l}-0.018 \\
(0.012)\end{array}$ & $\begin{array}{c}-0.014 \\
(0.013)\end{array}$ & $\begin{array}{c}-0.025^{* *} \\
(0.012)\end{array}$ & $\begin{array}{c}-0.025^{* *} \\
(0.012)\end{array}$ & $\begin{array}{c}-0.023^{* *} \\
(0.011)\end{array}$ & $\begin{array}{l}-0.110 \\
(0.119)\end{array}$ \\
\hline New workplace organization & $\begin{array}{c}-0.033 \\
(0.022)\end{array}$ & $\begin{array}{c}-0.023 \\
(0.028)\end{array}$ & $\begin{array}{c}-0.034^{* *} \\
(0.016)\end{array}$ & $\begin{array}{c}-0.024 \\
(0.020)\end{array}$ & $\begin{array}{c}-0.021^{*} \\
(0.012)\end{array}$ & $\begin{array}{c}-0.041^{* *} \\
(0.021)\end{array}$ \\
\hline \multicolumn{7}{|l|}{ Openness } \\
\hline Export share & $\begin{array}{c}0.023 \\
(0.048)\end{array}$ & $\begin{array}{c}0.018 \\
(0.048)\end{array}$ & $\begin{array}{c}-0.034 \\
(0.036)\end{array}$ & $\begin{array}{l}-0.033 \\
(0.036)\end{array}$ & $\begin{array}{c}-0.066^{* *} \\
(0.029)\end{array}$ & $\begin{array}{l}-0.063 \\
(0.067)\end{array}$ \\
\hline Foreign ownership & $\begin{array}{c}-0.060^{*} \\
(0.034)\end{array}$ & $\begin{array}{c}-0.060^{*} \\
(0.034)\end{array}$ & $\begin{array}{c}-0.056^{*} \\
(0.029)\end{array}$ & $\begin{array}{c}-0.055^{*} \\
(0.029)\end{array}$ & $\begin{array}{c}-0.084^{* *} \\
(0.023)\end{array}$ & $\begin{array}{l}-0.014 \\
(0.039)\end{array}$ \\
\hline Outsourcing of tasks & $\begin{array}{c}-0.027^{* *} \\
(0.011)\end{array}$ & $\begin{array}{c}-0.030^{* *} \\
(0.014)\end{array}$ & $\begin{array}{c}-0.021^{* *} \\
(0.008)\end{array}$ & $\begin{array}{c}-0.020^{*} \\
(0.012)\end{array}$ & $\begin{array}{c}-0.012^{*} \\
(0.007)\end{array}$ & $\begin{array}{c}-0.031^{* *} \\
(0.016)\end{array}$ \\
\hline \multicolumn{7}{|l|}{ Institutions } \\
\hline Mark-up power & $\begin{array}{c}-0.015^{* *} \\
(0.007)\end{array}$ & $\begin{array}{c}-0.014^{*} \\
(0.007)\end{array}$ & $\begin{array}{c}-0.013^{* *} \\
(0.006)\end{array}$ & $\begin{array}{c}-0.013^{* *} \\
(0.006)\end{array}$ & $\begin{array}{c}-0.011^{* *} \\
(0.004)\end{array}$ & $\begin{array}{l}-0.011 \\
(0.008)\end{array}$ \\
\hline Coverage rate & $\begin{array}{c}0.014 \\
(0.012)\end{array}$ & $\begin{array}{c}0.013 \\
(0.012)\end{array}$ & $\begin{array}{c}0.016 \\
(0.011)\end{array}$ & $\begin{array}{c}0.015 \\
(0.011)\end{array}$ & $\begin{array}{c}0.020^{* *} \\
(0.010)\end{array}$ & $\begin{array}{c}0.052^{* *} \\
(0.021)\end{array}$ \\
\hline Observations & 1,204 & 1,204 & 1,851 & 1,851 & 2,519 & 1,407 \\
\hline$R^{2}$ & 0.326 & 0.331 & 0.316 & 0.317 & 0.304 & 0.347 \\
\hline Controls & Yes & Yes & Yes & Yes & Yes & Yes \\
\hline Industry-year dummies & Yes & Yes & Yes & Yes & Yes & Yes \\
\hline Canton-year dummies & Yes & Yes & Yes & Yes & Yes & Yes \\
\hline
\end{tabular}

Robust standard errors in parentheses

$$
\text { ** } \mathrm{p}<0.05, * \mathrm{p}<0.1
$$

Controls: Business cycle controls and firm size and age dummies 
Table 5: Extensions

\begin{tabular}{|c|c|c|c|c|c|c|}
\hline VARIABLES & $\begin{array}{c}(1) \\
\text { POLS }\end{array}$ & $\begin{array}{c}(2) \\
\text { POLS }\end{array}$ & $\begin{array}{c}(3) \\
\text { POLS }\end{array}$ & $\begin{array}{l}\text { (4) } \\
\mathrm{FE}\end{array}$ & $\begin{array}{c}(5) \\
\text { POLS } \\
\text { Selected }\end{array}$ & $\begin{array}{c}\text { (6) } \\
\text { FE } \\
\text { Selected }\end{array}$ \\
\hline FDI & $\begin{array}{c}-0.058^{*} \\
(0.034)\end{array}$ & & & & & \\
\hline Number of competitors & & $\begin{array}{c}0.021^{* *} \\
(0.007)\end{array}$ & & & & \\
\hline Intensity of price competition & & $\begin{array}{c}-0.002 \\
(0.007)\end{array}$ & & & & \\
\hline Intensity of non-price competition & & $\begin{array}{c}-0.018^{* *} \\
(0.007)\end{array}$ & & & & \\
\hline Share of FTE female employees & & & $\begin{array}{c}-0.032^{* *} \\
(0.012)\end{array}$ & $\begin{array}{c}-0.072^{*} \\
(0.040)\end{array}$ & $\begin{array}{c}-0.079 * * \\
(0.027)\end{array}$ & $\begin{array}{c}-0.167^{*} \\
(0.091)\end{array}$ \\
\hline \multicolumn{7}{|l|}{ Production technology } \\
\hline Investment-output ratio & $\begin{array}{c}0.017^{* *} \\
(0.008)\end{array}$ & $\begin{array}{c}0.018^{* *} \\
(0.007)\end{array}$ & $\begin{array}{c}0.019^{* *} \\
(0.007)\end{array}$ & $\begin{array}{c}0.014^{*} \\
(0.008)\end{array}$ & $\begin{array}{c}0.051^{* *} \\
(0.015)\end{array}$ & $\begin{array}{c}0.014 \\
(0.020)\end{array}$ \\
\hline ICT use intensity & $\begin{array}{c}-0.140^{* *} \\
(0.043)\end{array}$ & $\begin{array}{c}-0.129 * * \\
(0.035)\end{array}$ & $\begin{array}{c}-0.110^{* *} \\
(0.037)\end{array}$ & $\begin{array}{l}-0.072 \\
(0.050)\end{array}$ & $\begin{array}{c}0.024 \\
(0.080)\end{array}$ & $\begin{array}{c}0.118 \\
(0.111)\end{array}$ \\
\hline New patents in last 3 years & $\begin{array}{l}-0.008 \\
(0.012)\end{array}$ & $\begin{array}{c}-0.028^{* *} \\
(0.012)\end{array}$ & $\begin{array}{c}-0.029 * * \\
(0.014)\end{array}$ & $\begin{array}{l}-0.009 \\
(0.013)\end{array}$ & $\begin{array}{l}-0.024 \\
(0.015)\end{array}$ & $\begin{array}{c}0.839^{* *} \\
(0.309)\end{array}$ \\
\hline New workplace organization & $\begin{array}{l}-0.015 \\
(0.014)\end{array}$ & $\begin{array}{c}-0.025^{* *} \\
(0.011)\end{array}$ & $\begin{array}{c}-0.027^{* *} \\
(0.011)\end{array}$ & $\begin{array}{l}-0.006 \\
(0.012)\end{array}$ & $\begin{array}{l}-0.022 \\
(0.033)\end{array}$ & $\begin{array}{c}-0.059 \\
(0.037)\end{array}$ \\
\hline \multicolumn{7}{|l|}{ Openness } \\
\hline Export share & $\begin{array}{c}-0.068^{* *} \\
(0.034)\end{array}$ & $\begin{array}{c}-0.077^{* *} \\
(0.027)\end{array}$ & $\begin{array}{c}-0.079^{* *} \\
(0.029)\end{array}$ & $\begin{array}{c}-0.139^{*} \\
(0.073)\end{array}$ & $\begin{array}{l}-0.050 \\
(0.065)\end{array}$ & $\begin{array}{c}-0.136^{*} \\
(0.074)\end{array}$ \\
\hline Foreign ownership & $\begin{array}{c}-0.075^{* *} \\
(0.026)\end{array}$ & $\begin{array}{c}-0.055^{* *} \\
(0.020)\end{array}$ & $\begin{array}{c}-0.048^{* *} \\
(0.021)\end{array}$ & $\begin{array}{c}-0.020 \\
(0.033)\end{array}$ & $\begin{array}{l}-0.016 \\
(0.046)\end{array}$ & $\begin{array}{c}0.136 \\
(0.089)\end{array}$ \\
\hline Outsourcing of tasks & $\begin{array}{c}-0.014 \\
(0.009)\end{array}$ & $\begin{array}{c}-0.016^{* *} \\
(0.007)\end{array}$ & $\begin{array}{c}-0.013^{*} \\
(0.007)\end{array}$ & $\begin{array}{c}-0.018^{* *} \\
(0.008)\end{array}$ & $\begin{array}{c}-0.028^{*} \\
(0.015)\end{array}$ & $\begin{array}{c}-0.032 \\
(0.023)\end{array}$ \\
\hline \multicolumn{7}{|l|}{ Institutions } \\
\hline Mark-up power & $\begin{array}{c}-0.012^{* *} \\
(0.005)\end{array}$ & & $\begin{array}{c}-0.013^{* *} \\
(0.004)\end{array}$ & $\begin{array}{c}-0.008 \\
(0.006)\end{array}$ & $\begin{array}{l}-0.015 \\
(0.012)\end{array}$ & $\begin{array}{c}-0.002 \\
(0.011)\end{array}$ \\
\hline Coverage rate & $\begin{array}{c}0.039 * * \\
(0.012)\end{array}$ & $\begin{array}{c}0.032^{* *} \\
(0.009)\end{array}$ & $\begin{array}{c}0.032^{* *} \\
(0.010)\end{array}$ & $\begin{array}{c}0.016 \\
(0.014)\end{array}$ & $\begin{array}{l}-0.010 \\
(0.018)\end{array}$ & $\begin{array}{c}-0.066 \\
(0.061)\end{array}$ \\
\hline Observations & 2,282 & 3,926 & 3,480 & 3,480 & 673 & 686 \\
\hline Business cycle controls & Yes & Yes & Yes & Yes & Yes & Yes \\
\hline Firm size and age controls & Yes & Yes & Yes & Yes & Yes & Yes \\
\hline Industry-year dummies & Yes & Yes & Yes & Yes & Yes & Yes \\
\hline Canton-year dummies & Yes & Yes & Yes & Yes & Yes & Yes \\
\hline Firm fixed dummies & No & No & No & Yes & No & Yes \\
\hline RMSE & 0.386 & 0.369 & 0.372 & 0.134 & 0.387 & 0.108 \\
\hline
\end{tabular}




\section{Online Appendix}

\section{Definition and measurement of variables}

Construction of skill-group specific wage bill:

We construct average wages in Switzerland for the three educational groups within cells defined in terms of the three-digit industry (NACE Revision 2), firm size class (more or less than 500 employees), and year using the wage structure survey (LSE). Employing these cell-specific wages from the wage structure survey, we can distribute the total wage bill $\left(w_{i, t}^{\text {Total }}\right)$ across the three skill groups $(q)$ using, first, the calculated average wages from the LSE $\left(w_{q, t}^{s, j}\right)$ in the firm's size class $(s)$ and industry $(j)$, and, second, the respective share of employees of the skill group $\left(e_{q, i, t}=E_{q, i, t} / \sum_{q} E_{q, i, t}\right)$ in the firm. Formally, the skill group-specific wage bill $w_{q, i, t}$ in time $t$ is computed using the following formula:

$$
w_{q, i, t}=w_{i, t}^{\text {Total }} * \frac{w_{q, t}^{s, j} * e_{q, i, t}}{\sum_{q}\left(w_{q, t}^{s, j} * e_{q, i, t}\right)} .
$$




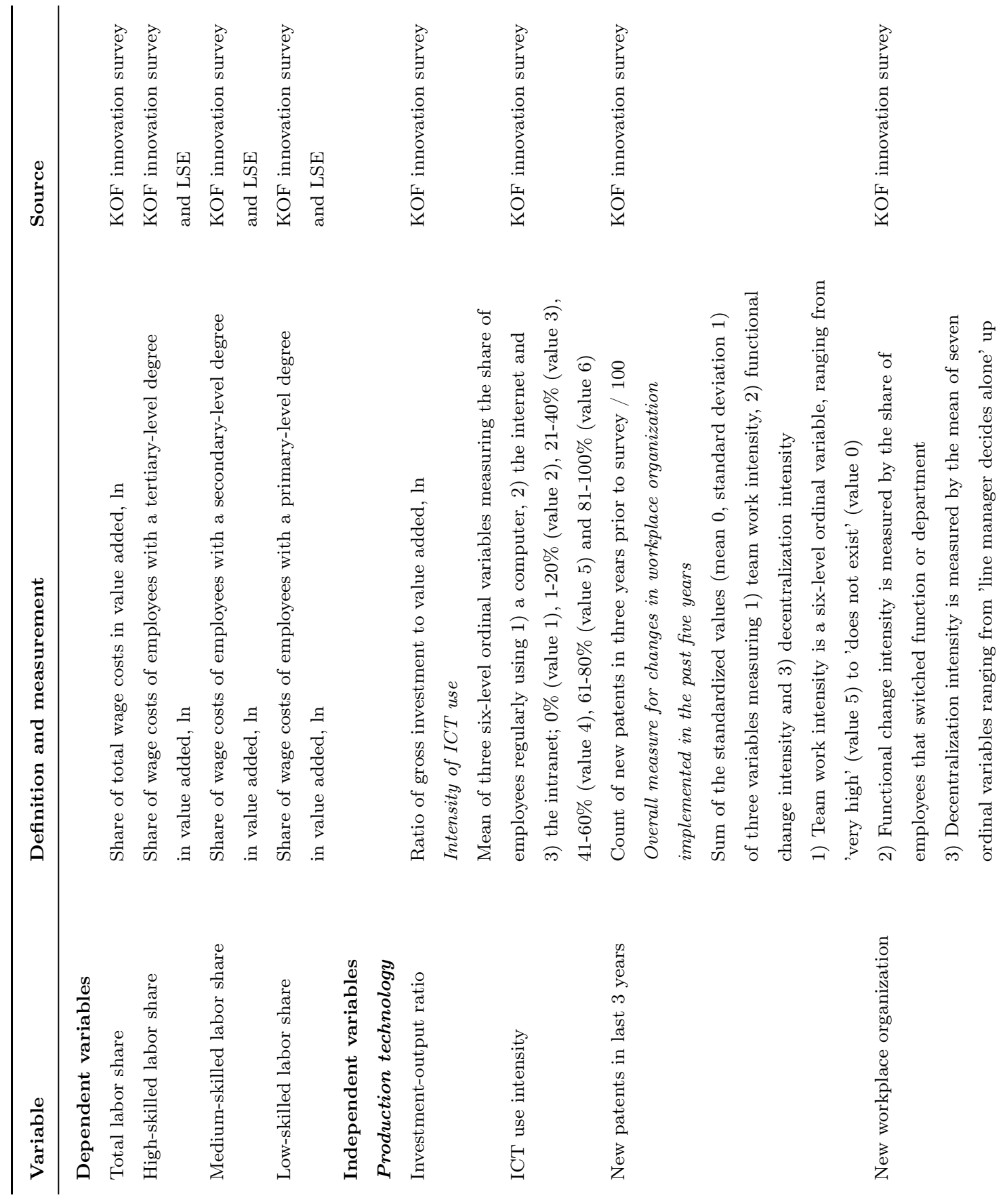




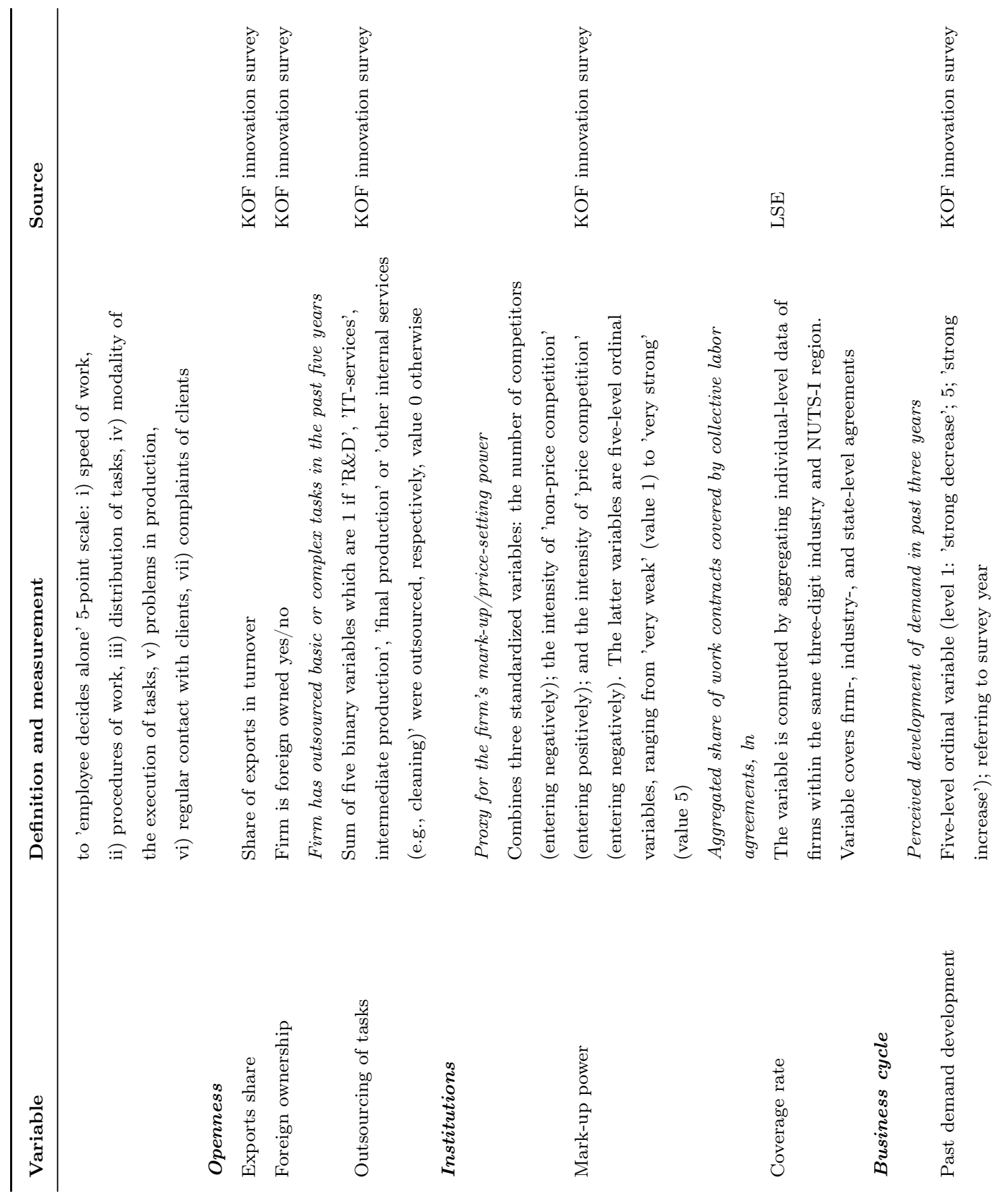




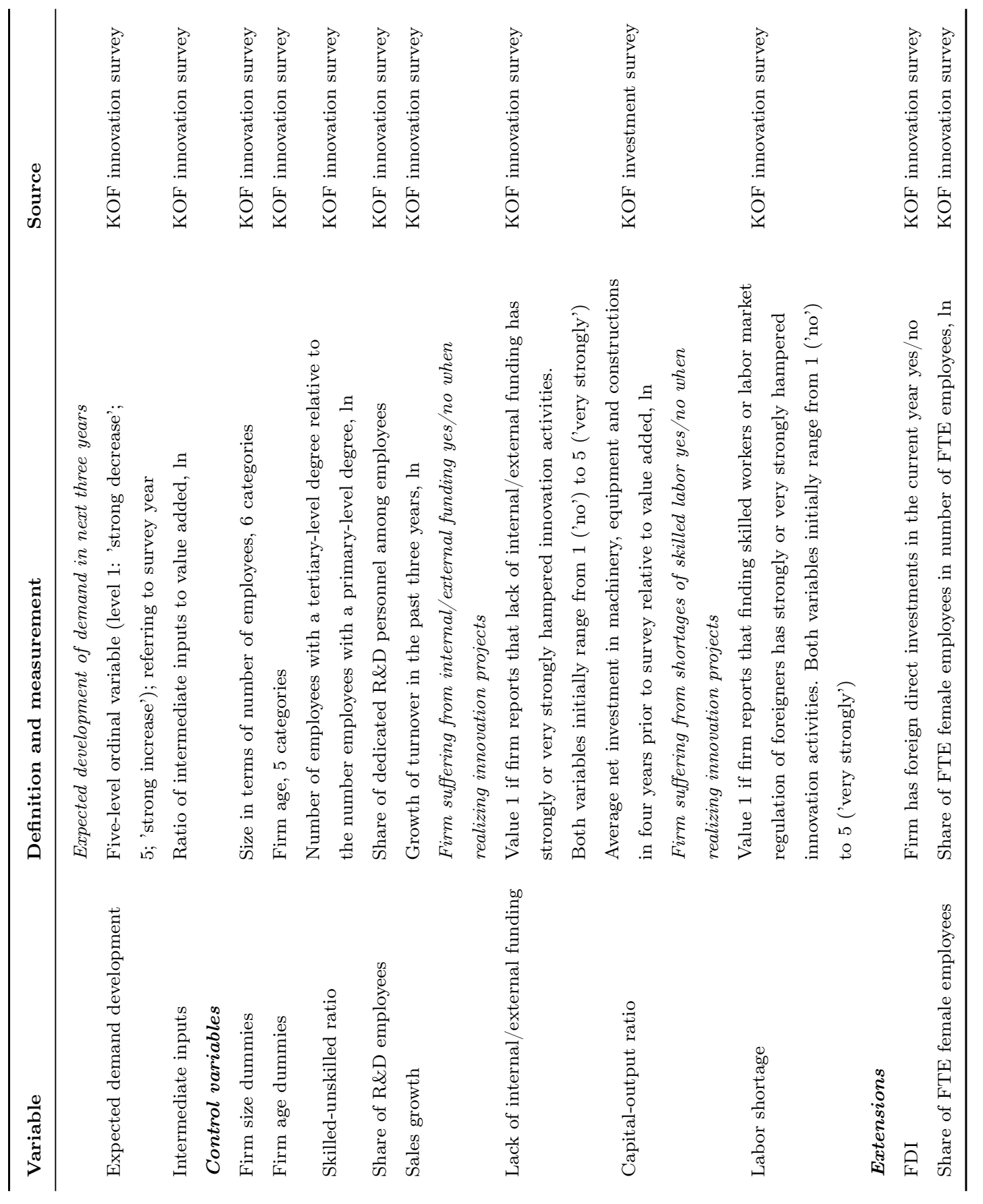




\section{Additional tables}

Table A.2: Firm-level labor shares by year and firm characteristics

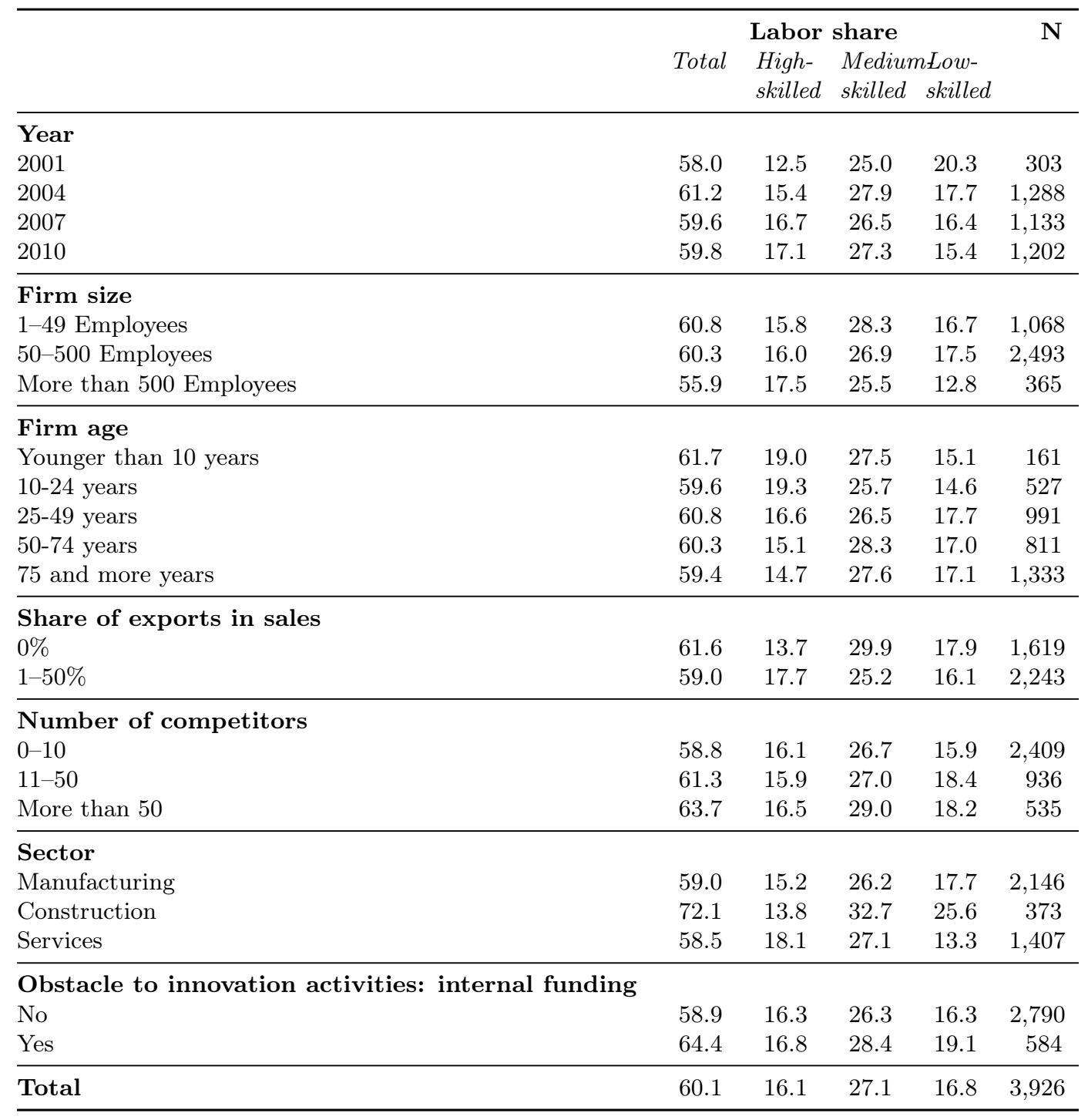


Table A.3: Alternative specifications of control variables

\begin{tabular}{|c|c|c|c|c|c|c|}
\hline VARIABLES & $\begin{array}{c}(1) \\
\text { POLS }\end{array}$ & $\begin{array}{c}(2) \\
\text { POLS }\end{array}$ & $\begin{array}{c}(3) \\
\text { POLS } \\
\end{array}$ & $\begin{array}{c}4) \\
\text { POLS }\end{array}$ & $\begin{array}{c}5) \\
\text { POLS }\end{array}$ & $\begin{array}{c}(6) \\
\text { POLS }\end{array}$ \\
\hline Skilled-unskilled ratio & $\begin{array}{c}-0.003 \\
(0.009)\end{array}$ & & & & & \\
\hline Share of R\&D employees & & $\begin{array}{c}0.001 \\
(0.001)\end{array}$ & & & & \\
\hline Sales growth & & & $\begin{array}{l}-0.014 \\
(0.015)\end{array}$ & & & \\
\hline Lack of internal funding & & & & $\begin{array}{c}0.072^{* *} \\
(0.021)\end{array}$ & & \\
\hline Lack of external funding & & & & $\begin{array}{l}-0.018 \\
(0.025)\end{array}$ & & \\
\hline Capital-output ratio & & & & & $\begin{array}{c}0.033^{* *} \\
(0.015)\end{array}$ & \\
\hline Labor shortage & & & & & & $\begin{array}{c}0.025 \\
(0.018)\end{array}$ \\
\hline \multicolumn{7}{|l|}{ Production technology } \\
\hline Investment-output ratio & $\begin{array}{c}0.019^{* *} \\
(0.007)\end{array}$ & $\begin{array}{c}0.021^{* *} \\
(0.007)\end{array}$ & $\begin{array}{c}0.013 \\
(0.010)\end{array}$ & $\begin{array}{c}0.019^{* *} \\
(0.007)\end{array}$ & & $\begin{array}{c}0.018^{* *} \\
(0.007)\end{array}$ \\
\hline ICT use intensity & $\begin{array}{c}-0.125^{* *} \\
(0.036)\end{array}$ & $\begin{array}{c}-0.117^{* *} \\
(0.035)\end{array}$ & $\begin{array}{c}-0.149^{* *} \\
(0.052)\end{array}$ & $\begin{array}{c}-0.147^{* *} \\
(0.038)\end{array}$ & $\begin{array}{c}-0.127^{*} \\
(0.071)\end{array}$ & $\begin{array}{c}-0.150^{* *} \\
(0.038)\end{array}$ \\
\hline New patents in last 3 years & $\begin{array}{c}-0.027^{* *} \\
(0.012)\end{array}$ & $\begin{array}{c}-0.020^{*} \\
(0.011)\end{array}$ & $\begin{array}{c}-0.022^{* *} \\
(0.011)\end{array}$ & $\begin{array}{c}-0.028^{* *} \\
(0.012)\end{array}$ & $\begin{array}{c}0.000 \\
(0.077)\end{array}$ & $\begin{array}{c}-0.028^{* *} \\
(0.012)\end{array}$ \\
\hline New workplace organization & $\begin{array}{c}-0.022^{* *} \\
(0.011)\end{array}$ & $\begin{array}{c}-0.028^{* *} \\
(0.011)\end{array}$ & $\begin{array}{l}-0.017 \\
(0.016)\end{array}$ & $\begin{array}{c}-0.021^{*} \\
(0.012)\end{array}$ & $\begin{array}{l}-0.025 \\
(0.020)\end{array}$ & $\begin{array}{c}-0.020^{*} \\
(0.012)\end{array}$ \\
\hline \multicolumn{7}{|l|}{ Openness } \\
\hline Export share & $\begin{array}{c}-0.082^{* *} \\
(0.027)\end{array}$ & $\begin{array}{c}-0.090 * * \\
(0.029)\end{array}$ & $\begin{array}{c}-0.078^{*} \\
(0.044)\end{array}$ & $\begin{array}{c}-0.077^{* *} \\
(0.029)\end{array}$ & $\begin{array}{c}-0.106^{*} \\
(0.057)\end{array}$ & $\begin{array}{c}-0.079^{* *} \\
(0.029)\end{array}$ \\
\hline Foreign ownership & $\begin{array}{c}-0.055^{* *} \\
(0.020)\end{array}$ & $\begin{array}{c}-0.059^{* *} \\
(0.020)\end{array}$ & $\begin{array}{c}-0.076^{* *} \\
(0.030)\end{array}$ & $\begin{array}{c}-0.058^{* *} \\
(0.021)\end{array}$ & $\begin{array}{l}-0.042 \\
(0.040)\end{array}$ & $\begin{array}{c}-0.060^{* *} \\
(0.021)\end{array}$ \\
\hline Outsourcing of tasks & $\begin{array}{c}-0.016^{* *} \\
(0.007)\end{array}$ & $\begin{array}{c}-0.012^{*} \\
(0.007)\end{array}$ & $\begin{array}{l}-0.014 \\
(0.011)\end{array}$ & $\begin{array}{c}-0.016^{* *} \\
(0.007)\end{array}$ & $\begin{array}{c}-0.033^{* *} \\
(0.014)\end{array}$ & $\begin{array}{c}-0.015^{* *} \\
(0.007)\end{array}$ \\
\hline \multicolumn{7}{|l|}{ Institutions } \\
\hline Mark-up power & $\begin{array}{c}-0.011^{* *} \\
(0.004)\end{array}$ & $\begin{array}{c}-0.011^{* *} \\
(0.004)\end{array}$ & $\begin{array}{l}-0.007 \\
(0.006)\end{array}$ & $\begin{array}{c}-0.012^{* *} \\
(0.004)\end{array}$ & $\begin{array}{l}-0.008 \\
(0.007)\end{array}$ & $\begin{array}{c}-0.013^{* *} \\
(0.004)\end{array}$ \\
\hline Coverage rate & $\begin{array}{c}0.029 * * \\
(0.009)\end{array}$ & $\begin{array}{c}0.036^{* *} \\
(0.010)\end{array}$ & $\begin{array}{c}0.032^{* *} \\
(0.014)\end{array}$ & $\begin{array}{c}0.025^{* *} \\
(0.009)\end{array}$ & $\begin{array}{c}0.018 \\
(0.016)\end{array}$ & $\begin{array}{c}0.026^{* *} \\
(0.009)\end{array}$ \\
\hline Observations & 3,836 & 3,696 & 1,881 & 3,374 & 852 & 3,374 \\
\hline$R^{2}$ & 0.297 & 0.291 & 0.304 & 0.314 & 0.415 & 0.312 \\
\hline Controls & Yes & Yes & Yes & Yes & Yes & Yes \\
\hline Industry-year dummies & Yes & Yes & Yes & Yes & Yes & Yes \\
\hline Canton-year dummies & Yes & Yes & Yes & Yes & Yes & Yes \\
\hline
\end{tabular}

Robust standard errors in parentheses

$$
\text { ** } \mathrm{p}<0.05, * \mathrm{p}<0.1
$$

Controls: Business cycle controls and firm size and age dummies 
Table A.4: Preferred specification with standard errors robust to clustering on regionindustry level

\begin{tabular}{|c|c|c|c|c|}
\hline VARIABLES & $\begin{array}{c}(1) \\
\text { POLS } \\
\end{array}$ & $\begin{array}{c}(2) \\
\text { High-skilled } \\
\text { labor share }\end{array}$ & $\begin{array}{c}(3) \\
\text { Medium-skilled } \\
\text { labor share }\end{array}$ & $\begin{array}{c}\text { (4) } \\
\text { Low-skilled } \\
\text { labor share }\end{array}$ \\
\hline \multicolumn{5}{|l|}{ Production technology } \\
\hline Investment-output ratio & $\begin{array}{c}0.016^{* *} \\
(0.007)\end{array}$ & $\begin{array}{c}0.006 \\
(0.012)\end{array}$ & $\begin{array}{c}0.014 \\
(0.011)\end{array}$ & $\begin{array}{c}0.084^{* *} \\
(0.016)\end{array}$ \\
\hline ICT use intensity & $\begin{array}{c}-0.144^{* *} \\
(0.038)\end{array}$ & $\begin{array}{c}0.715^{* *} \\
(0.093)\end{array}$ & $\begin{array}{c}0.030 \\
(0.057)\end{array}$ & $\begin{array}{c}-1.308^{* *} \\
(0.115)\end{array}$ \\
\hline New patents in last 3 years & $\begin{array}{c}-0.037^{* *} \\
(0.017)\end{array}$ & $\begin{array}{c}0.003 \\
(0.022)\end{array}$ & $\begin{array}{c}-0.071^{* *} \\
(0.020)\end{array}$ & $\begin{array}{c}-0.170 * * \\
(0.027)\end{array}$ \\
\hline New workplace organization & $\begin{array}{c}-0.023^{* *} \\
(0.010)\end{array}$ & $\begin{array}{c}0.130^{* *} \\
(0.025)\end{array}$ & $\begin{array}{l}-0.024 \\
(0.022)\end{array}$ & $\begin{array}{c}-0.134^{* *} \\
(0.030)\end{array}$ \\
\hline \multicolumn{5}{|l|}{ Openness } \\
\hline Export share & $\begin{array}{c}-0.076 * * \\
(0.029)\end{array}$ & $\begin{array}{c}0.286^{* *} \\
(0.046)\end{array}$ & $\begin{array}{c}-0.308^{* *} \\
(0.046)\end{array}$ & $\begin{array}{l}-0.107 \\
(0.069)\end{array}$ \\
\hline Foreign ownership & $\begin{array}{c}-0.054^{* *} \\
(0.020)\end{array}$ & $\begin{array}{c}-0.074^{*} \\
(0.043)\end{array}$ & $\begin{array}{l}-0.050 \\
(0.035)\end{array}$ & $\begin{array}{c}-0.126^{* *} \\
(0.057)\end{array}$ \\
\hline Outsourcing of tasks & $\begin{array}{c}-0.015^{* *} \\
(0.007)\end{array}$ & $\begin{array}{c}0.011 \\
(0.012)\end{array}$ & $\begin{array}{c}-0.039 * * \\
(0.012)\end{array}$ & $\begin{array}{c}0.011 \\
(0.015)\end{array}$ \\
\hline \multicolumn{5}{|l|}{ Institutions } \\
\hline Mark-up power & $\begin{array}{c}-0.013^{* *} \\
(0.004)\end{array}$ & $\begin{array}{c}0.001 \\
(0.009)\end{array}$ & $\begin{array}{c}-0.016^{* *} \\
(0.008)\end{array}$ & $\begin{array}{c}-0.039 * * \\
(0.010)\end{array}$ \\
\hline Coverage rate & $\begin{array}{c}0.024^{* *} \\
(0.010)\end{array}$ & $\begin{array}{c}0.004 \\
(0.017)\end{array}$ & $\begin{array}{l}0.027^{*} \\
(0.015)\end{array}$ & $\begin{array}{c}0.033^{* *} \\
(0.017)\end{array}$ \\
\hline $\begin{array}{l}\text { Observations } \\
R^{2}\end{array}$ & $\begin{array}{l}3,706 \\
0.293\end{array}$ & 3,706 & 3,706 & 3,706 \\
\hline Controls & Yes & Yes & Yes & Yes \\
\hline Industry-year dummies & Yes & Yes & Yes & Yes \\
\hline Canton-year dummies & Yes & Yes & Yes & Yes \\
\hline
\end{tabular}

Robust standard errors in parentheses

$* * \mathrm{p}<0.05, * \mathrm{p}<0.1$

Controls: Business cycle controls and firm size and age dummies 